05

\title{
Современное состояние разработки светочувствительных сред для голографии (обзор)
}

\author{
(C) В.А. Барачевский \\ Центр фотохимии, ФНИЦ „Кристаллография и фотоника“ РАН, \\ 119421 Москва, Россия \\ Межведомственный центр аналитических исследований \\ в области фозики, химии и биологии при Президиуме РАН, \\ 117997 Москва, Россия \\ e-mail: barva@photonics.ru
}

Поступила в редакцию 20.10.2017 г.

\begin{abstract}
Проведен анализ результатов исследований, выполненных за последние 10 лет в области разработки галогенид-серебряных и несеребряных голографических регистрирующих сред органического и неорганического происхождения. Показано, что ранее разработанные материалы в основном обеспечивают развитие голографических исследований. Среди необратимых материалов значительный прогресс достигнут в совершенствовании характеристик фотополимеризующихся регистрирующих сред, что обеспечило их применение в цветной изобразительной голографии, 3D оптической памяти архивного типа и для изготовления голографических оптических элементов. В области совершенствования свойств реверсивных голографических регистрирующих сред получены практически значимые результаты для создания фотоанизотропных материалов на основе азокрасителей, испытывающих цис-транс-фотоизомеризацию, обеспечивающих регистрацию поляризационных голограмм. Потребности динамической голографии удовлетворяются созданными светочувствительными допированными неорганическими кристаллами и полимерными слоями с нелинейнооптическими свойствами.
\end{abstract}

DOI: $10.21883 /$ OS.2018.03.45659.238-17

\section{1. Введение}

Развитие голографической науки и ее практические результаты в значительной степени зависят от состояния разработки светочувствительных голографических материалов, свойства которых определяют конкретную область их применения в голографии. В связи с этим в обзоре последовательно рассмотрены результаты разработки необратимых и обратимых светочувствительных регистрирующих сред для изобразительной голографии, изготовления голографических оптических элементов (ГОЭ) и применения в информационных фототехнологиях.

Данный обзор достижений в области разработки светочувствительных регистрирующих сред является логическим продолжением ранее выполненных аналитических исследований до 2007 г. [1,2] и представляет анализ результатов исследований, полученных в основном за последние 10 лет.

\section{2. Необратимые светочувствительные среды}

\section{1. Галогенид-серебряные фотоматериалы}

Галогенид-серебряные мелкозернистые фотоматериалы представляют для голографии особый интерес в силу их наибольшей светочувствительности по сравнению с другими голографическими регистрирующими средами, высокой разрешающей способности и широкого диапазона спектральной чувствительности, обеспечиваемой фотосенсибилизаторами. Размер микрокристаллов галогенида серебра в таких эмульсионных материалах обычно составляет $10-100 \mathrm{~nm}$, что позволяет получать регистрирующие среды с разрешающей способностью до $7000 \mathrm{~mm}^{-1}$. Наибольшее применение в голографии получили зарубежные материалы типа ВB640 и BB520 (HRT GmbH, Германия), Agfa 8E75HD, Agfa 8E и Kodak 649, а также отечественные фотоматериалы ОАО „Славич“ (Россия) [3].

Развитие исследований в этой области голографических регистрирующих сред определяется ограниченными возможностями применения изобразительной голографии и большим научным заделом, достигнутым в первые десятилетия развития голографии. К настоящему времени создан большой ассортимент светочувствительных высокоразрешающих голографических галогенидсеребряных монохромных и цветных фотоматериалов, который оказался достаточным для удовлетворения потребностей, ограниченных в основном копированием музейных ценностей, изготовлением портретов и созданием произведений искусства [4]. Этот ассортимент материалов выпускается как на стеклянной (табл. 1), так и на пленочной (табл. 2) основе. Размеры фотопластин могут изменяться в широких пределах: от $50 \times 50$ до $406 \times 609 \mathrm{~mm}^{2}$. Фотопленки выпускаются в виде рулонов и листов требуемого размера. 
Таблица 1. Характеристики голографических галогенид-серебряных фотопластинок

\begin{tabular}{|c|c|c|c|c|c|}
\hline Наименование показателя & ВРП-М & ПФГ-01 & ПФГ-03М & ПФГ-03Ц & ПФГ-04 \\
\hline $\begin{array}{l}\text { Общая светочувствительность, } \\
S_{0.9}, \text { ед. ГОСТ }\end{array}$ & $0.012-0.030$ & - & - & - & - \\
\hline $\begin{array}{l}\text { Длина волны записывающего } \\
\text { лазерного излучения, } \lambda_{\mathrm{rec}}, \mathrm{nm}\end{array}$ & 530 & 633 & 633 & $457,530,633$ & 488 \\
\hline $\begin{array}{l}\text { Дифракционная эффективность, } \\
\eta \%, \text { не менее }\end{array}$ & - & 35 & 40 & 40 & 70 \\
\hline $\begin{array}{l}\text { Голографическая чувствительность, } \\
\mathrm{H}, \mathrm{J} / \mathrm{m}^{2}\end{array}$ & - & 1.5 & 20 & 40 & 2500 \\
\hline Плотность вуали, $D_{0}, \mathrm{~B}$, не более & 0.02 & - & - & - & - \\
\hline $\begin{array}{l}\text { Граница области спектральной } \\
\text { сенсибилизации, nm, не более }\end{array}$ & 565 & 650 & 680 & 680 & - \\
\hline $\begin{array}{l}\text { Разрешающая способность, } \\
R, \mathrm{~mm}^{-1} \text {, не менее }\end{array}$ & 1570 & - & - & - & - \\
\hline $\begin{array}{l}\text { Температура деформации } \\
\text { эмульсионного слоя, }{ }^{\circ} \mathrm{C}, \text { не менее }\end{array}$ & 50 & 90 & 34 & 34 & 34 \\
\hline Нанос металлического серебра, g/m² & $3.0 \pm 0.2$ & $\begin{array}{l}2.6 \pm 0.2 \\
3.3 \pm 0.1\end{array}$ & $1.6 \pm 0.1$ & $3.2 \pm 0.1$ & - \\
\hline Толщина фотослоя, $\mu \mathrm{m}$ & $6 \pm 1$ & $6 \pm 1$ & $7 \pm 1$ & $10.5 \pm 1$ & $20 \pm 2$ \\
\hline
\end{tabular}

Таблица 2. Характеристики голографических галогенид-серебряных фотопленок

\begin{tabular}{|c|c|c|c|c|c|}
\hline Наименование показателя & ВРП-М & ПФГ-017 & ПФГ-03М & ПФГ-03Ц & ПФГ-04 \\
\hline $\begin{array}{l}\text { Длина волны записывающего } \\
\text { лазерного излучения, } \lambda_{\text {rec }}, \mathrm{nm}\end{array}$ & 530 & 633 & 633 & $457,530,633$ & 488 \\
\hline $\begin{array}{l}\text { Дифракционная эффективность, } \\
\eta \%, \text { не менее }\end{array}$ & 40 & 40 & 45 & 45 & 70 \\
\hline $\begin{array}{l}\text { Голографическая чувствительность, } \\
\mathrm{H}, \mathrm{J} / \mathrm{m}^{2}\end{array}$ & 1.0 & 1.0 & 20 & 30 & $2500-3000$ \\
\hline $\begin{array}{l}\text { Граница области спектральной } \\
\text { сенсибилизации, nm, не более }\end{array}$ & 565 & 650 & 680 & 680 & - \\
\hline $\begin{array}{l}\text { Температура деформации } \\
\text { эмульсионного слоя, }{ }^{\circ} \mathrm{C}, \text { не менее }\end{array}$ & 90 & 90 & 34 & 34 & 34 \\
\hline Толщина фотослоя, $\mu \mathrm{m}$ & $6.5 \pm 1$ & $7 \pm 1$ & $7 \pm 1$ & $10 \pm 1$ & $12-15$ \\
\hline
\end{tabular}

Для фотоматериалов типа ПФГ-03М и ПФГ-ЗЦ была повышена чувствительность к синему лазерному излучению путем улучшения условий проявления и за счет использования сенсибилизаторов [5]. Выявлены пути повышения чувствительности высокоразрешающих галогенид-серебряных голографических регистрирующих сред к ИК излучению [6]. В результате обработки материала триэтаноламином с последующим кратковременным его нагреванием при $75^{\circ} \mathrm{C}$ чувствительность материала к излучению с длиной волны $\lambda=1.06 \mu \mathrm{m}$ удалось повысить на 4 порядка, а к излучению с $\lambda=1.3 \mu \mathrm{m}-$ на 2 порядка. Область спектральной чувствительности была расширена до $1.7 \mu \mathrm{m}$.

Фотопластинки ПФГ-01 были использованы для изготовления диффузоров путем регистрации мультиплексных голограмм [7]. Усовершенствованные галогенид- серебряные фотоматериалы оказались пригодными для изготовления высококачественных оптических элементов [8].

Применение галогенид-серебряных материалов в голографии ограничивается тем, что они нуждаются в мокром проявлении, испытывают необратимые фотопревращения для получения изображения, обладают существенным поглощением и шумами, обусловленными светорассеянием светочувствительных нанокристаллов.

\section{2. Слои бихромированной желатины}

Слои бихромированной желатины отличаются от многих голографических регистрирующих сред тем, что они обеспечивают получение голограмм высокого оп- 
Таблица 3. Голографические характеристики фотополимеризующихся полимерных композиций

\begin{tabular}{c|l|c|c|c|c|c}
\hline № п/п & \multicolumn{1}{|c|}{ Регистрирующая среда } & $d, \mu \mathrm{m}$ & $\Delta \lambda, \mathrm{nm}$ & $\eta, \%$ & $\lambda_{\text {rec }}, \mathrm{nm}$ & $S, \mathrm{~mJ} / \mathrm{cm}^{2}$ \\
\hline 1 & Акриламидная & 75 & $400-500$ & 80 & 488 & 12 \\
2 & Акриламид-акрилатная & 15 & $400-500$ & 80 & 488 \\
3 & Акрилатные: & & & & \\
& Du Рont $\left(\mathrm{HRF}^{\odot}\right.$, Omnidex $\left.^{\odot}\right)$ & 50 & $300-700$ & 90 & $488,532,692$ & $1-100$ \\
& Polaroid Corporation (DMP-128) & & $442-647$ & $80-95$ & $488,532,692$ & 5 \\
& ФПК-488 (CCCP) & & $300-500$ & 100 & 488 & 20 \\
4 & Золь-гелевая & & $400-500$ & $60-80$ & 488 & $0.1-1.0$ \\
& & & $400-500$ & 90 & 488 & 1
\end{tabular}

Примечание. $d$ - толщина среды, $\Delta \lambda$ - область спектральной чувствительности, $\eta-$ дифракционная эффективность, $\lambda_{\text {гес }}-$ длина волны записывающего лазерного излучения, $S$ - светочувствительность.

тического качества с высокой величиной дифракционой эффективности (ДЭ). Они остаются привлекательными для изготовления ГОЭ, особенно больших размеров, используемых в частности для изготовления селективных концентраторов фотовольтаических и фотохимических преобразователей солнечной энергии [9].

Слои бихромированной желатины, содержащие нитрат серебра, оказались пригодными для получения голографическим методом фотонных кристаллов, допированных серебром [10], изготовления рельефных голографических решеток, используемых в лазерах с распределенной обратной связью [11].

В слое на основе рыбной желатины и бихромата аммония впервые в реальном времени излучением аргонового лазера $(\lambda=458 \mathrm{~nm})$ получены голограммы с ДЭ около $14 \%$ [12]. Они, однако, имеют низкое разрешение $\left(264 \mathrm{~mm}^{-1}\right)$.

\section{3. Фотополимеры}

К числу необратимых голографических регистрирующих сред относятся полимерные материалы, которое обеспечивают необратимую регистрацию голограмм в результате процесса ионной или радикальной фотополимеризации мономерно-сополимерных композиций. В основной состав фотополимеризующихся материалов (фотополимеров) входят в основном три компонента: фотоинициатор, один или несколько мономеров и полимерное связующее. Последнее обеспечивает механическую стабильность регистрирующей среды, совместимость с входящими в него компонентами и высокое оптическое качество. Кроме того, в состав этих материалов могут входить пластификаторы, ингибиторы реакций, стабилизаторы, сшивающие реагенты, наночастицы и др.

Фотополимеры обеспечивают регистрацию и восстановление голограмм в реальном времени с рекордно высокой разрешающей способностью и ДЭ, а также малыми шумами. Возможность сенсибилизации процессов фотополимеризации молекулами красителей позволяет создавать среды, чувствительные к излучению в широ- ком спектральном диапазоне, в том числе для регистрации цветных голограмм. К числу недостатков этих регистрирующих сред следует отнести на три порядка более низкую величину светочувствительности по сравнению с галогенид-серебряными материалами; усадку толщины материала, что приводит к искажению голограмм. Для устранения последнего недостатка используются композиции, испытывающие катионную фотополимеризацию, а также содержащие два мономера с различным механизмом фотополимеризации [3]. Кроме того, в состав композиций вводятся неорганические нефотоактивные наночастицы и применяются светочувствительные зольгелевые композиции.

Механизм фотохимических и фотофизических процессов, осуществляющихся в фотополимеризующихся композициях, достаточно хорошо изучен и промоделирован [13], что позволяет успешно оптимизировать характеристики голографических сред этого типа [14]. С целью оптимизации компонентного состава и улучшения свойств фотополимеризующихся композиций проведен ряд теоретических исследований взаимосвязи между процессами полимеризации и диффузии мономеров $[15,16]$, а также регистрации объемных голограмм [17] и мультиплексных изображений $[18,19]$.

Характеристики основных типов фотополимеров, разработанных для регистрации и восстановления голограмм, представлены в табл. 3 [3].

Высокие голографические свойства проявляют фотополимеризующиеся акрилатные композиции, содержащие соли $\mathrm{FeCl}_{3}$ [20].

Ключевым компонентом фотополимеризующихся композиций является фотоинициирующая система, которая определяет величину и спектральный диапазон светочувствительности голографических сред этого типа. Сравнительное исследование свойств различных красителей, фотоинициирующих процесс радикальной фотополимеризации ПВС/акриламидных композиций, показало, что для обеспечения более высокой светочувствительности целесообразно использовать (Phloxine B), который наименее подвержен влиянию кислорода на фотопроцессы [21]. Установлено, что 
2-(4-(N,N-диметиламино)бензилиден)-1Н-инден-1,3(2Н)дион I является эффективным фотосенсибилизатором/ фотоинициатором как радикальной, так и катионной фотополимеризации [22].

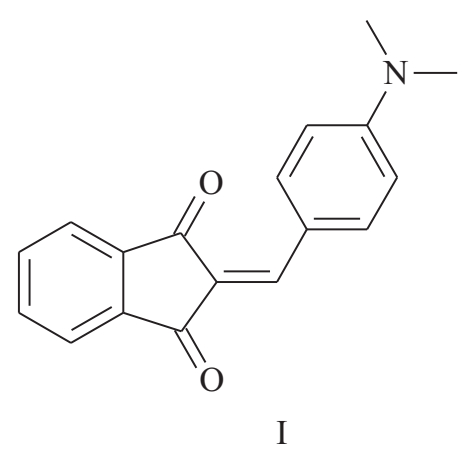

Для уретан-акрилатных композиций, содержащих в составе фотоинициирущей системы пиррометиновый краситель II, эффективность процесса фотополимеризации существенно увеличивалась после введения амина III как донора, а также производного тризина IV и соли иода $1250 \mathrm{~V}$, использованного в качестве акцептора электрона [23].<smiles>CCOC(=O)c1ccc(N(C)C)cc1</smiles>

II

III<smiles>COc1ccc(C2=NC(C(Cl)(Cl)Cl)NC(C(Cl)(Cl)Cl)=N2)cc1</smiles>

IV

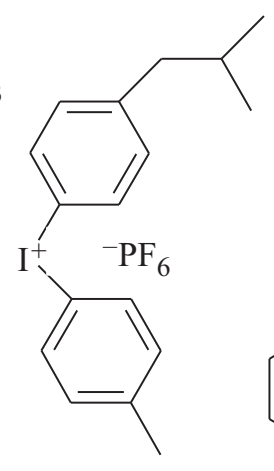

V<smiles>O=C(O)CNc1ccccc1</smiles>

VI
Дальнейшее исследование показало, что оптимальными свойствами обладает трехкомпонентная фотоинициирующая система II-V-IV с использованием $N$-фенилг̄лицина, которая обеспечивает повышение светочувствительности за счет фотоциклической реакции (схема 1) [24].

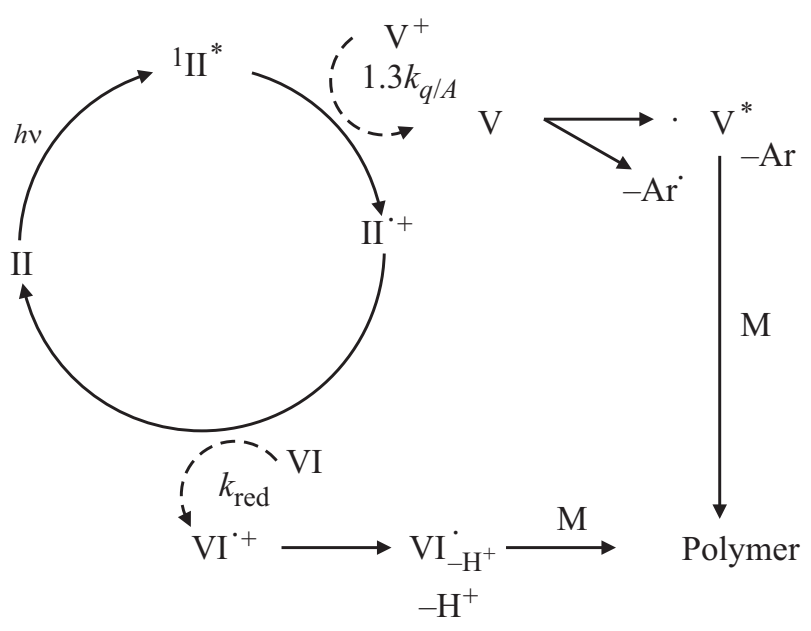

Scheme 1

Эффективная фотополимеризация достигалась и при использовании в качестве красителей Розы Бенгальской VII или Сафронина VIII, а в качестве акцептора электронов - производого биимидазола (2,2-бис (2хлорфенил)-4, 4 5, 5-тетрафенил-1, 2-биимидазол) IX в присутствии со-инициатора $N$-фенилглицина VI [25].<smiles>[NH3+]Oc1c(I)cc2c(-c3c(Cl)c(Cl)c(Cl)c(Cl)c3C(=O)[O-])c3cc(I)c(=O)c(I)c-3oc2c1I</smiles>

VII<smiles>[R4]CC(c1ccccc1Cl)(c1ccccc1Cl)n1c(-c2ccccc2Cl)nc(-c2ccccc2)c1-c1ccccc1</smiles>

Фотополимеризующиеся ПВС/акриламидные композиции при низкой концентрации красителя (Метиленовый Голубой, $C=10^{-4}-10^{-5} \mathrm{M}$ ) обеспечивают регистрацию голограмм с $\eta=62 \%$ при экспозициях 
$5 \mathrm{~mJ} / \mathrm{cm}^{2}$ без применения сшивающего компонента [26]. Время жизни этой композиции существенно увеличивается при ее хранении при $4^{\circ} \mathrm{C}$.

Разработанные эпоксидные фотополимеризующиеся среды могут использоваться для регистрации как пропускающих, так и отражательных голограмм [27]. В слоях толщиной $200 \mu \mathrm{m}$ пропускающие голограммы с $\eta=100 \%$ регистрировались при экспозициях $0.5 \mathrm{~J} / \mathrm{cm}^{2}$. Разрешающая способность достигала $8000 \mathrm{~mm}^{-1}$. Для регистрации голограмм использовались также фотополимеризующиеся композиции, содержащие низкомолекулярный полидиметилсилоксан с концевыми гидроксильными группами, эпоксид-содержащий сшивающий реагент, фотополимеризуемый акрилатный мономер и фотоинициатор в золь-гелевой кремнеземной матрице [28]. Для стабилизации эпоксидных фотополимеризующихся композиций в процессе их темнового хранения в их состав вводились перехватчики радикалов, в частности 4-метоксифенол [29].

Для улучшения оптических характеристик сухого фотополимера с фотополимеризующейся композицией в ПММА матрице дополнительно вводился сшивающий реагент [30]. Введение в состав ПВС/акриламидной фотополимеризующейся композиции сшивающего агента позволило повысить ДЭ регистрируемых голограмм $(532 \mathrm{~nm})$, увеличить стабильность голограмм при хранении и устойчивость к влаге [31].

Повышению светочувствительности, ДЭ голограмм и разрешающей способности фотополимеризующихся композиций способствует введение в их состав имидазольных, пиридиниевых и фосфониевых ионных жидкостей [32].

Исследовано влияние температуры и влажности на свойства голограмм, зарегистрированных в ПВС/акриламидных фотополимеризующихся средах [33].

Для повышения безопасности работы с фотополимерными композициями вместо акриламидных регистрирующих сред были предложены нетоксичные композиции на основе диацетонакриламида, которые обеспечивают регистрацию голограмм с ДЭ более 90\% в слоях толщиной $70 \mu \mathrm{m}$ [34]. Резкое снижение токсичности доказано экспериментально [35]. При этом фотоиндуцированное изменение показателя преломления составляло $\Delta n=3.3 \cdot 10^{-3}$, что лишь на $20 \%$ ниже, чем для ПВС/акриламидных регистрирующих сред. Введение в состав композиции глицерина, который играет роль пластификатора, позволило увеличить скорость диффузии радикалов и тем самым повысить светочувствительность регистрирующей среды [36]. При этом скорость фотополимеризации возрастала на 60\% [37]. Кроме того, оказалось, что глицерин повышает стабильность композиций и улучшает оптическое качество голограмм [38]. Регистрирующие среды этого типа обеспечивают получение отражательных голограмм с ДЭ, достигающей 50\% [39].

К числу малотоксичных фотополимеризующихся материалов относится голографическая среда Биофотопол, в котором токсичный акриламид заменен акрилатом натрия, а в качестве красителя использовался водорастворимый рибофлавин [40]. В состав композиции в качестве сшивающего реагента вводился малотоксичный $N, N^{\prime}$ (1,2-дигидроксиэтилен)бисакриламид. Фотоинициатором служил рибофлавин в комбинации с триэтаноламином в низкой концентрации. Слои Биофотопола толщиной $900 \mu \mathrm{m}$ обеспечивали получение голограмм с $\eta=77 \%$ при экспозиции $200 \mathrm{~mJ} / \mathrm{cm}^{2}$. Угловая чувствительность составляла $0.2^{\circ}$.

Для регистрации голограмм предлагаются слои поливинилацетатного клея, содержащие бихромат аммония $(C=4$ вес.\%) [41]. Эти слои характеризуются высокой адгезией к различным подложкам, устойчивостью к влажности, низкой стоимостью и не требуют мокрой или температурной обработки. Голограммы регистрируются лазерным излучением с длиной волны $332 \mathrm{~nm}$. Они характеризуются $\eta=21 \%$ при экспозициях около $1.25 \mathrm{~J} / \mathrm{cm}^{2}$. В компонентный состав добавляют также акриламид $\mathrm{X}$ [42].

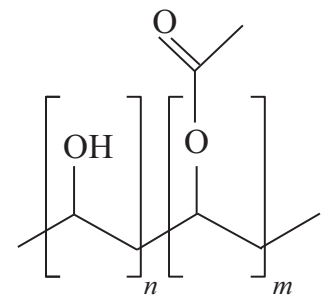

$\mathrm{X}$

В катионной фотополимеризующейся среде экспериментально реализована двухфотонная регистрация микроголограмм в 10 слоях с плотностью записи информации $7 \cdot 10^{10} \mathrm{bit} / \mathrm{cm}^{3}[43]$.

Фотополимеризующиеся среды толщиной $130 \mu \mathrm{m}$ на основе ПВС/акриламидной системы с Метиленовым голубым $(\mathrm{M \Gamma})\left(C=0.14 \cdot 10^{-4} \mathrm{M}\right)$ были использованы для получения отражательных голограмм с $\eta=2.84 \%$ при экспозиции $300 \mathrm{~mJ} / \mathrm{cm}^{2}$ [44].

Состав фотополимеризующейся ПВС/акриламидной композиции был оптимизирован для импульсной регистрации голограмм лазерным излучением с длиной

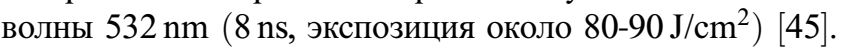

Благодаря высоким значениям фотоиндуцированного изменения показателя преломления и широкому динамическому диапазону ПВС/акриламидные фотополимеризующиеся композиции представляют интерес для создания устройств оптической памяти. Для увеличения информационной емкости регистрирующей среды этого типа использовался метод мультиплексирования голограмм на одном и том же участке регистрирующего поля с использованием жидкокристаллического устройства, формирующего изображения [46].

Среди фотополимеризующихся материалов наибольший коммерческий интерес в настоящее время представляют разработанные фирмой Байер (Германия) свето- 

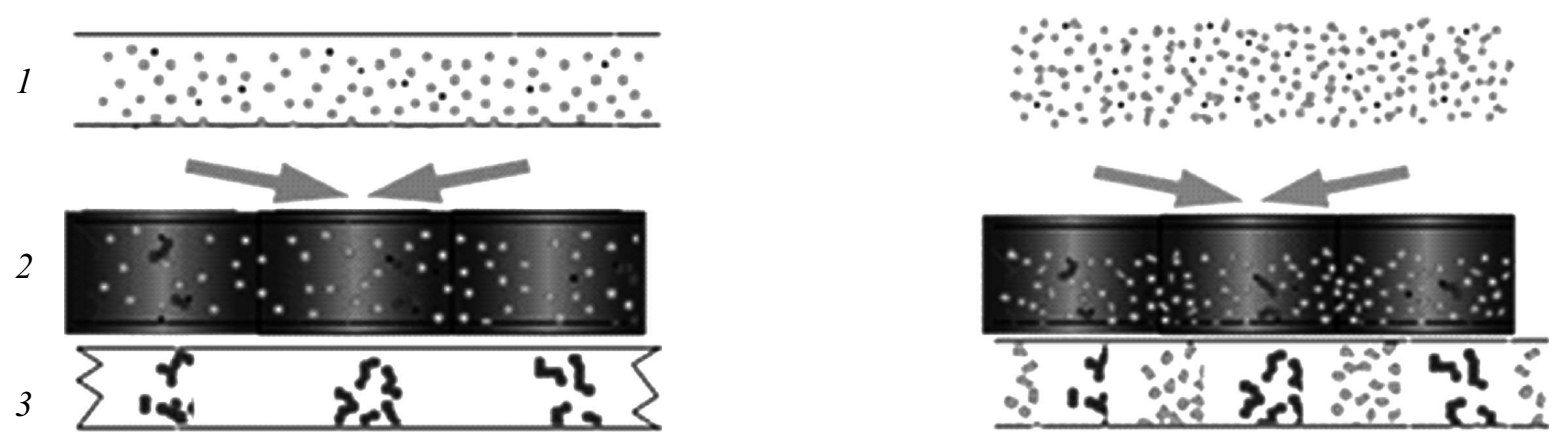

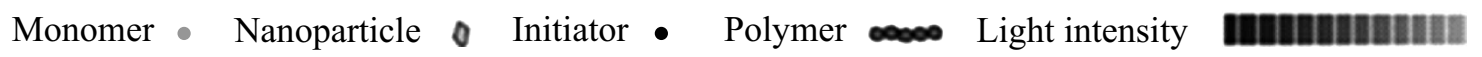

Рис. 1. Механизм регистрации голограмм в фотополимере без $(a)$ и с наночастицами $(b)$ до(1), в процессе $(2)$ и после $(3)$ регистрации голограммы [59].

чувствительные пленки на основе акрилатной композиции BMS, обеспечивающие регистрацию цветных голограмм $[47,48]$. По сравнению с известными ПВС/акриламидными композициями она обладает более высокой светочувствительностью, в 3 раза большим фотоиндуцированным изменением показателя преломления, высокой разрешающей способностью и возможностью регистрации высококачественных отражательных голограмм. Разработка данной среды была основана на результатах моделирования фотохимических и фотофизических процессов в фотополимеризующейся среде $[49,50]$.

Для создания 3D оптической памяти архивного типа использовалась фотополимеризующаяся регистрирующая среда с широким динамическим диапазоном регистрации голограмм DRED [51,52], состоящая из двух полимерных систем, одна из которых образует полимерную матрицу, а вторая, состоящая из мономеров и фотоинициирующей системы, полимеризуется под действием света с образованием голограмм. Эта регистрирующая среда обеспечивает создание объемной голографической памяти в виде оптических дисков с плотностью записи до 4 [53-56] и даже $8 \mathrm{~TB} / \mathrm{in}^{2}$ [52]. Эта среда отличается низкой себестоимостью, низкими энергетическими затратами по сравнению с магнитными дисками [57].

Помимо рассмотренных выше усовершенствований фотополимеризующихся композиций, основное внимание было обращено на разработку композиций, содержащих наночастицы различного типа. Механизм фотополимеризации таких композитных материалов состоит в перемещении наночастиц из облученных в необлученные участки интерференционной решетки (рис. 1) [58,59].

Из рис. 1 видно, что в случае композитного материала наночастицы вытесняются из освещенных участков интерференционной картины в затемненные, а мономеры устремляются в освещенные участки регистрирующего слоя, как и в слое без наночастиц, и об- разуют полимер. В результате получаются голографические решетки с высокой ДЭ. На рис. 2 приведены зависимости величины ДЭ голограмм, зарегистрированных в фотополимеризующейся композиции, включающей 2-карбоксиэтил-акрилат, глицеролат Бисфенола А, 2-феноксиэтил-акрилат, от времени экспозиции без и в присутствии наночастиц $\mathrm{ZnO}$ [60]. Видно, что введение наночастиц приводит к резкому возрастанию величины ДЭ.

Совершенствование фотополимеризующихся акрилатных композиций с наночастицами позволило создать регистрирующие среды на основе двух мономеров с различной реакционной способностью и наночастиц $\mathrm{SiO}_{2}, \mathrm{TiO}_{2}, \mathrm{ZrO}_{2}$. Эти среды обеспечивали получение дифракционных решеток с периодом 0.38-2.1 $\mu \mathrm{m}$ и модуляцию показателя преломления в диапазоне $\Delta n=0.006-0.024[61]$. Такие композиты могут быть использованы для изготовления $1 D$ - и $2 D$-голографических элементов, используемых при создании лазеров с распределенной обратной связью, а также фотоуправляемых фотонных кристаллов [62]. Введение люминесцирующих наночастиц в фотополимеризующиеся композиции

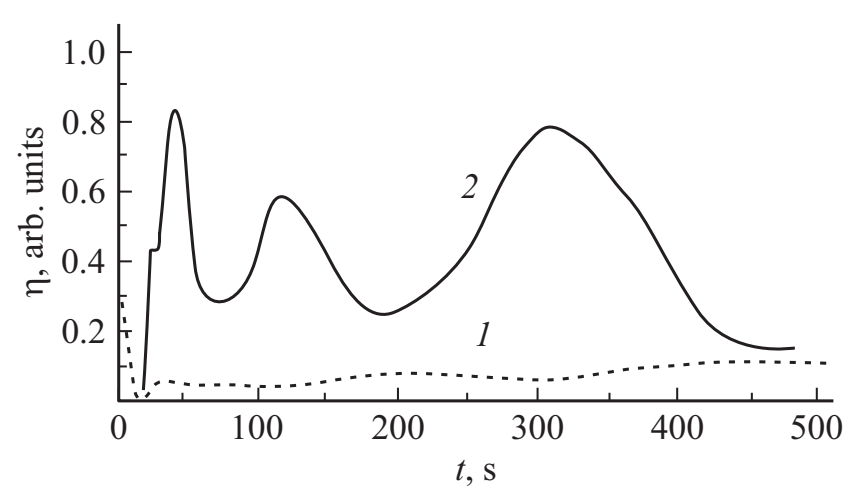

Рис. 2. Зависимость ДЭ регистрируемых голограмм от времени экспонирования в фотополимере без (1) и в присутствии (2) наночастиц $\mathrm{ZnO}[60]$. 
обеспечивает их применение в качестве меток для идентификации изделий.

Композитные системы на основе акрилатных мономеров и полиуретана, содержащие 35 вес.\% наночастиц $\mathrm{SiO}_{2}$ в смеси с силановыми соединениями, имеющими длинные алкильные и винильные группы, позволили увеличить светочувствительность и повысить величину ДЭ голограмм до 93.6\% [63]. При этом усадка пленки толщиной $20 \mu \mathrm{m}$ составляла $2.9 \%$. Для тиольных фотополимеризующихся сред, содержащих наночастицы $\mathrm{SiO}_{2}$, усадка слоя на длине волны излучения лазерного диода $(\lambda=404 \mathrm{~nm})$ оказалась выше, чем на длине волны $\lambda=532 \mathrm{~nm}$ [64]. Голографические свойства тиольных композиций, содержащих наночастицы $\mathrm{SiO}_{2}$, могут быть улучшены за счет оптимизации мономерного состава композиции [65]. Для исследования усадки фотополимеризующихся композиций использовалась голографическая интерферометрия [66].

Введение наночастиц $\left(\mathrm{SiO}_{2}, \mathrm{TiO}_{2}, \mathrm{Mg}(\mathrm{OH})_{2}\right.$ и др. $)$ способствует улучшению характеристик фотополимеризующихся регистрирующих сред (светочувствительности, величины ДЭ). В частности, использование наночастиц $\mathrm{TiO}_{2}$ снижает усадку с $1.12 \%$ до $0.28 \%$ [67]. Присутствие наночастиц $\mathrm{SiO}_{2}(C=0.4 \mathrm{веc. \%})$ в ПВС/акриламидных композициях сокращает время регистрации голограмм на $55.7 \%$, а предварительная фотополимеризация увеличивает светочувствительность на 23.1\% [68].

Для получения толстых регистрирующих сред $(500 \mu \mathrm{m})$ разработан метод их получения с использованием акриловых композиций и наночастиц $\mathrm{ZrO}_{2}$ [69]. Разработаны голографические композитные фотополимеризующиеся среды с наночастицами $\mathrm{ZnS}$ [70].

В акриламидных фотополимеризующихся композици-

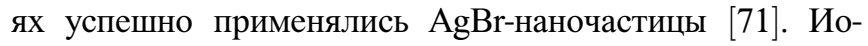
ны $\mathrm{Ag}^{+}$, используемые в качестве сшивающего реагента, позволяют регистрировать пропускающие голограммы высокого качества в реальном времени в ПВА/акриламидной композиции [72]. Для регистрации голограмм с ДЭ=70\% энергетические затраты излучения гелий-неонового лазера составляли $10 \mathrm{~mJ} / \mathrm{cm}^{2}$ [73].

Для предотвращения агрегации наночастиц $\mathrm{Au}$ в ПВС/акриламидных композициях наночастицы покрывали цитрат-ионами [74]. При этом ДЭ регистрируемых голограмм достигала $90 \%$, а усадка не превышала $0.8 \%$.

Регистрирующие фотополимеризующиеся материалы с низкой усадкой слоя $(0.5 \%)$ были получены на основе тиольных мономеров и наночастиц $\mathrm{SiO}_{2}$ [75]. Фотоиндуцированное изменение показателя преломления составляло $\Delta n=1 \cdot 10^{-2}$ при экспозиции $15 \mathrm{~mJ} / \mathrm{cm}^{2}$ [76]. В качестве наночастиц использовались квантовые точки $\mathrm{CdSe} / \mathrm{ZnS}$ [77].

На основе эпоксидной матрицы созданы голографические регистрирующие среды, содержащие наночастицы светочувствительного неорганического олигомерного вещества [78]. В акрилатных фотополимерных композициях в качестве наночастиц использовались органиче- ские дендримеры XI [79].

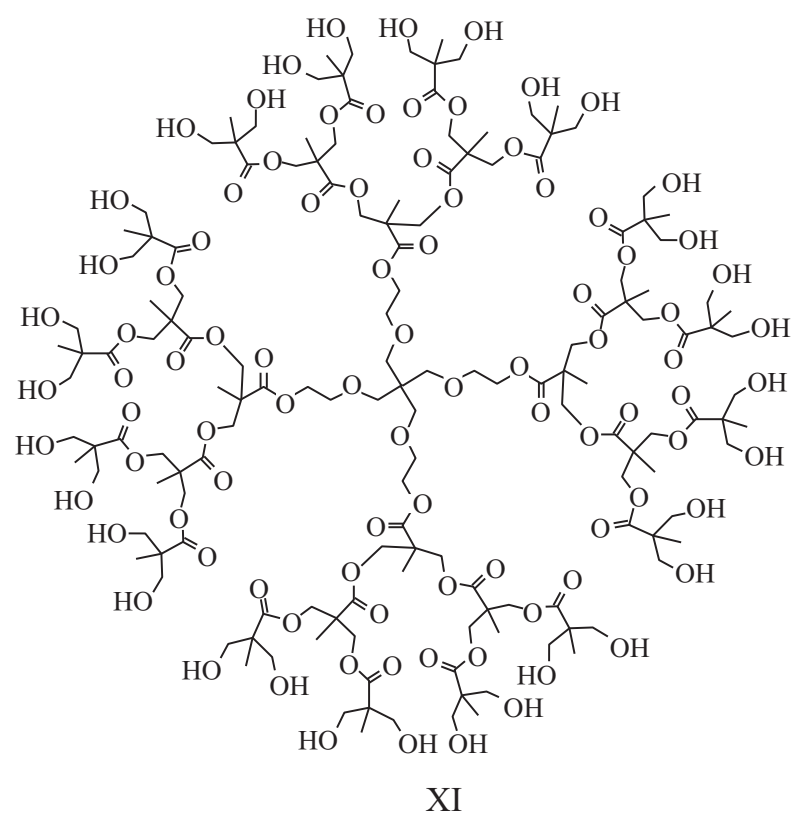

Голографические решетки, изготовленные в фотополимеризующейся регистрирующей среде, содержащей наночастицы $\mathrm{SiO}_{2}$, успешно использовались для исследования дифракции медленных нейтронов [80]. Акриловые среды этого типа, содержащие наночастицы $\mathrm{SiO}_{2}$, а также $\mathrm{Au}$, оказались пригодными для изготовления двумерных фотонных кристаллов [81]. Показана возможность создания оптической памяти с помощью толстослойных фотополимеризующихся регистрирующих сред, содержащих наночастицы $\mathrm{SiO}_{2}$ и тиольные композиции [82]. Лазерным излучением с длиной волны $\lambda=532 \mathrm{~nm}$ было зарегистрировано 180 голограмм со сдвиговым мультиплексированием, достигнута плотность записи информации $9 \mathrm{Mbit} / \mathrm{in}^{2}$. Акриловые фотополимеризующиеся композитные материалы, содержащие наночастицы $\mathrm{ZnO}$ и $\mathrm{SiO}_{2}$, использовались для $3 D$ голографической печати [83].

Несмотря на успехи в разработке фотополимеризующихся голографических сред, ряд характеристик, а именно время жизни, разрешающая способность, шумы, обусловленные светорассеянием, требуют дальнейшего улучшения. Детальный анализ полученных результатов в разработке фотополимеризующихся композиций был использован для уточнения направлений дальнейшего совершенствования голографических свойств регистрирующих сред этого типа [84].

\section{4. Полимерные светочувствительные среды}

Существенным недостатком фотополимеризующихся регистрирующих сред является усадка слоя в процессе регистрации голограмм и, как следствие, их искажение. Это обстоятельство представляется особенно важным при изготовлении (ГОЭ). В связи с этим были предложены светочувствительные полимер- 


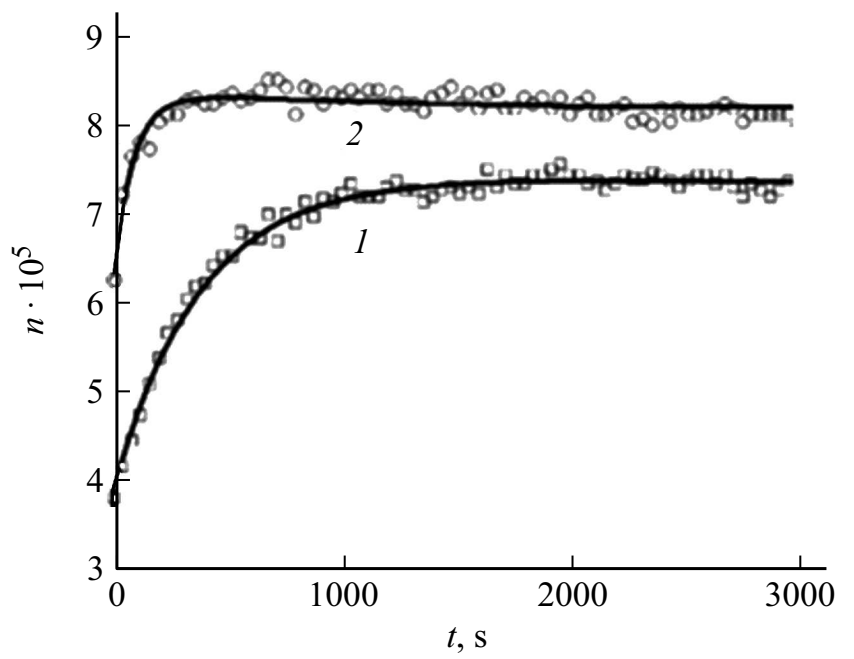

Рис. 3. Изменение показателя преломления среды ФХ-ПММА без (1) и в присутствии наночастиц $\mathrm{SiO}_{2}$ (2). Сплошные кривые получены в результате моделирования процессов [86].

ные среды, в которых регистрация голограмм осуществляется за счет введения в твердую полимерную матрицу, например ПММА, светочувствительных соединений, которые испытывают фотохимические превращения и химически связываются с полимерными молекулами [85]. Эти среды усиливают полученное изображение за счет диффузии непрореагировавших молекул и обеспечивают фотохимическую фиксацию голограмм. Схема 2 представляет фотохимические превращения светочувствительного фенантренхинона (ФX) XII [85].

В случае недополимеризованных регистрирующих сред этого типа голографические характеристики могут быть улучшены при введении в состав материала наночастиц $\mathrm{SiO}_{2}(C=0.1$ вес.\%) (рис. 3) [86]. За счет оптимизации условий регистрации и восстановления голограмм, а также процесса усиления ДЭ голограмм при их хранении в темноте удалось зарегистрировать голограммы с $\eta=82 \%$ в слоях толщиной $2 \mathrm{~mm}$ [87]. Введение в состав ФХ-ПММА материала $N, N$-диметил4-нитроанилина позволяло регистрировать в слое тол- щиной $2 \mathrm{~mm}$ голограммы с $\eta=43 \%$ излучением лазера с длиной волны $\lambda=647 \mathrm{~nm}[88]$.

Для повышения светочувствительности в состав материала ФХ-ПММА вводился металло-органический мономер - Zn-метакрилат [89]. Дополнительное введение в состав этого материала $N, N$-диметил-4-нитроанилина или его производных позволило повысить ДЭ голограмм до $86.2 \%$ [90,91].

Материал ФХ-ПММА использовался для регистрации поляризационных голограмм циркулярно-поляризованным лазерным излучением [92]. При такой записи среда обладает широким динамическим диапазоном и высокой светочувствительностью $\left(5.6 \mathrm{~J} / \mathrm{cm}^{2}\right)$. Величина ДЭ может достигать $\eta=0.0017 \%$ [93]. При концентрации ФХ $C=3 \mathrm{~mol} \%$, содержащейся в $200 \mu \mathrm{m}$ слое ПММА, регистрировались голограммы с $\eta=8 \%$ и угловой чувствительностью около $1.5^{\circ}$ [94]. Для получения голограмм с $\eta=16 \%$ в слоях толщиной несколько сотен микрон использовался также полимерный слой, включающий ФХ, ПММА и поливинилбутираль, размещенный между стеклянными пластинами $[95,84]$.

С целью улучшения термостабильности регистрируемых голограмм при температурах $60-70^{\circ} \mathrm{C}$ и улучшения адгезионных свойств полимерные слои с ФХ изготавливались с использованием смеси мономеров (метилметакрилата, метакриламида и метакриловой кислоты) [96], a также сополимеров метилметакрилата с акриловой кислотой [97].

Вместо ФХ использовались другие соединения, в частности ксантон, бензофенон. Для улучшения светочувствительности и повышения ДЭ голограмм в состав полимерных стекол толщиной до $2 \mathrm{~mm}$ вводились различные добавки, в том числе мономеры, наночастицы $\mathrm{SiO}_{2}$ и др. [85]. В результате были получены светочувствительные полимеры с рекордно высокими значениями величины ДЭ и угловой селективности, а также с низкой усадкой слоя. В слоях ПММА вместо ФХ применялся антрацилацетоборан дифторида, который при облучении испытывает фотохимическую димеризацию [98]. Отличительной особенностью этих слоев является то, что после регистрации голографического изображения в результате нагревания слоя при $75^{\circ} \mathrm{C}$ в течение $24 \mathrm{~h}$ величина ДЭ голограмм возрастала с 8 до 70\%. Для записи голограмм лазерным излучением с длиной волны $\lambda=532 \mathrm{~nm}$

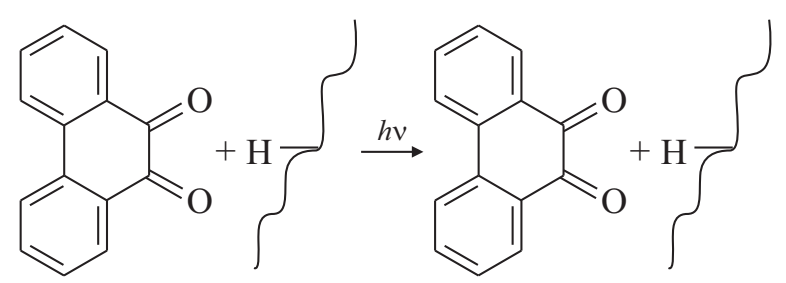

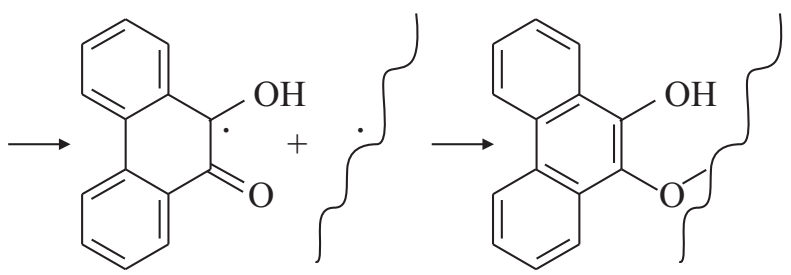

XII

Scheme 2 
предложена регистрирующая среда на основе ПММА и 3', 3"-дибромтимолсульфорфталеина XIII [99].<smiles>Cc1c(C2(c3cc(C(C)C)c(O)c(Br)c3C)OS(=O)(=O)c3ccccc32)cc(C(C)C)c(O)c1Br</smiles>

В таком слое в результате фотоиндуцированной радикальной реакции образования дигидрокрасителя наблюдалось фотоиндуцированное изменение показателя преломления $(\Delta n=0.0025)$, обеспечивающее регистрацию голограмм. Для получения полимерных слоев, чувствительных к лазерному излучению в диапазоне $500-600 \mathrm{~nm}$, в качестве полимерной матрицы использовалась нитроцеллюлоза, а фотосенсибилизатором служила соль хлорида железа $\left(\mathrm{FeCl}_{3}\right)$ [100].

В светочувствительных полимерных слоях на основе ПВС в качестве фотосенсибилизаторов использовались натуральные бетацианиновые пигменты [101]. Такие слои обеспечивали регистрацию голограмм с $\eta=23 \%$ при экспозиции около $1 \mathrm{~mJ} / \mathrm{cm}^{2}$. С использованием ферментированной опунции кактуса и ПВС получен голографический светочувствительный материал, отличающийся низкой стоимостью и незначительной токсичностью, в котором лазерным излучением с длиной волны $\lambda=442 \mathrm{~nm}$ регистрировались пропускающие голограммы с $\eta=32.2 \%$ при экспозиции $250 \mathrm{~mJ} / \mathrm{cm}^{2}$ [102].

Для повышения ДЭ голограмм, регистрируемых в светочувствительных слоях на основе ПВС и бихромата аммония, в состав материала вводили флуоресцирующие чернила, основным компонентом которых являлся флуорофор - пара-нитро-бензиловый спирт XIV (рис. 4) [103].<smiles>O=[N+]([O-])c1ccc(CO)cc1</smiles>

\section{XIV}

Применение в качестве флуорофоров квантовых точек (рис. 5), вводимых в гидрогели ПВС, позволяет использовать такие среды для цифровых голографических $3 D$ приложений [104].

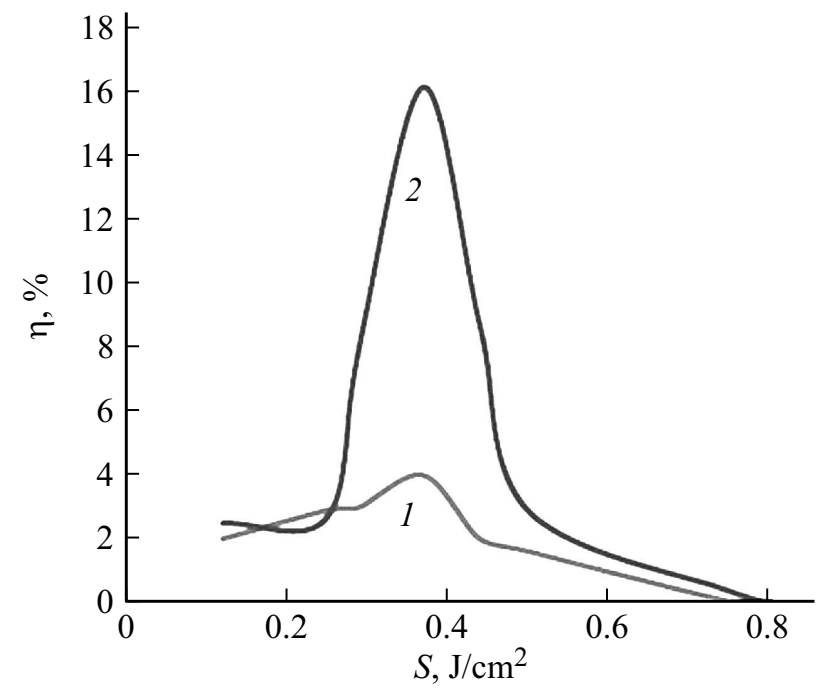

Рис. 4. Зависимость величины ДЭ голограмм, зарегистрированных в слое ПВС, содержащем бихромат аммония, от экспозиции без (1) и в присутствии флуорофора-пара-нитробензилового спирта (2) [103].

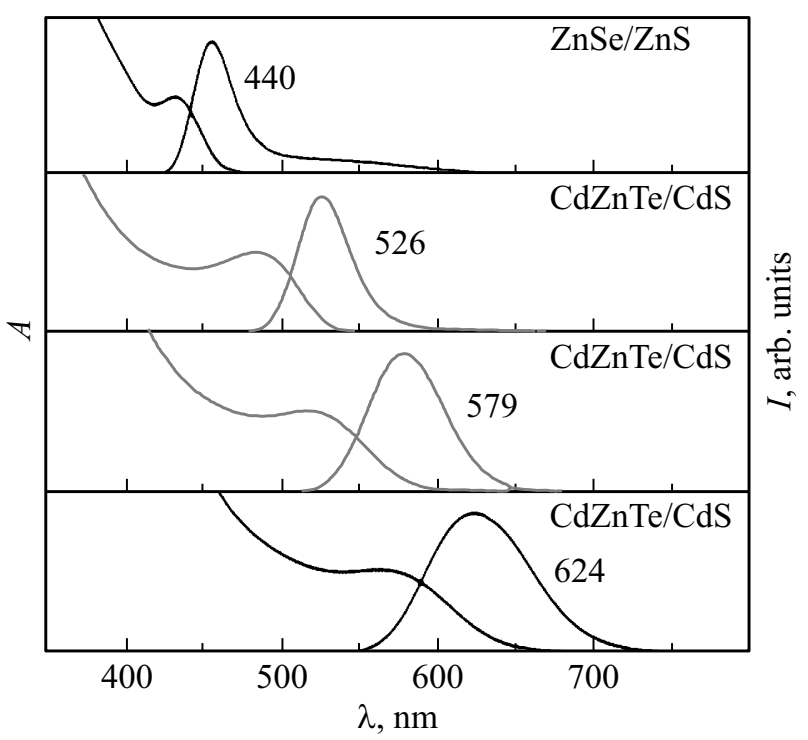

Рис. 5. Спектральные характеристики квантовых точек: спектры поглощения (кривые слева) и флуоресценции (кривые справа) [104].

Рельефные голограммы с $\eta>40 \%$ (после травления) регистрировали в полимерных слоях на основе карбазолсодержащих полимеров и иодоформа, образующих комплексы с переносом заряда [105].

\section{5. Неорганические светочувствительные слои}

Продолжается исследование голографических свойств халькогенидных слоев на основе а- $\mathrm{As}_{2} \mathrm{~S}_{3}$ с целью повышения их разрешающей способности [106]. Исследована зависимость образования рельефных голографических 
решеток от поляризации регистрирующих лазерных пучков в слоях халькогенидов $\mathrm{As}_{2} \mathrm{~S}_{3}$ и $\mathrm{As}-\mathrm{S}-\mathrm{Se}$, а также азокрасителя в полиуретановой пленке [107]. Показано, что направление массопереноса вещества определяется направлением электрического вектора и фотоиндуцированной анизотропии в пленках.

Рельефно-фазовые голографические элементы для ИК области получали в поликристаллических слоях $\mathrm{ZnSe}$ толщиной $2.4 \mu \mathrm{m}$, которые проявляют значительные фотоиндуцированные изменения показателя преломления $(\Delta n=1.73$ на длине волны $457 \mathrm{~nm}$ и $\Delta n=0.74-1.2$ на длине волны $10.6 \mu \mathrm{m})$ [108]. Рельефно-фазовые голографические решетки могут быть получены непосредственно в процессе их записи в многослойных наноструктурах $\mathrm{Ge}_{5} \mathrm{As}_{37} \mathrm{~S}_{58}-\mathrm{Se}$ [109]. В слоях $\mathrm{As}_{40} \mathrm{~S}_{60}: \mathrm{Mn}-\mathrm{Se}$ запись рельефных голографических решеток осуществлялась в магнитном поле [110].

\section{3. Обратимые светочувствительные среды}

\section{1. Фотохромные полимерные среды}

Впервые голограммы на фотохромных полимерных материалах, содержащих в качестве полимерного связующего ПММА и фотохромного соединения XV из класса нитрозамещенных индолиновых спиропиранов $\left(\mathrm{R}_{1}=\mathrm{H} ; \mathrm{R}_{2}=\mathrm{R}_{3}=\mathrm{R}_{4}=\mathrm{CH}_{3} ; \mathrm{R}_{5}=\mathrm{NO}_{2}\right.$ ) (схема 3), были зарегистрированы в 1965 г. [111]. Голограммы записывались излучением гелий-неонового лазера $(\lambda=633 \mathrm{~nm})$ после УФ индуцированного окрашивания бесцветной формы $A$ спиропирана с образованием окрашенной мероцианиновой формы $B$.

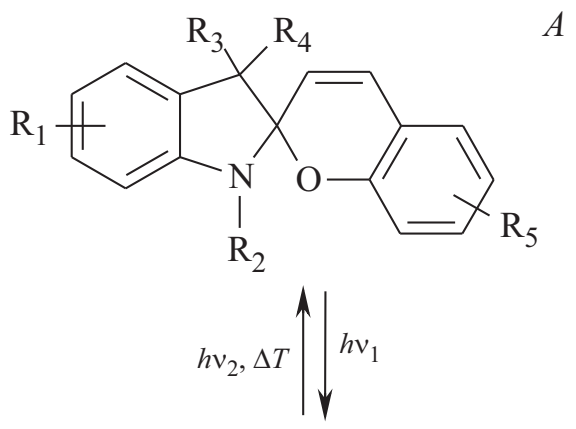<smiles>[R][R]C1=CC=CC(=O)C1=CC=C1N([R2])c2ccccc2C1([R3])[R4]</smiles>

Scheme 3

Характерной особенностью этих термически релаксирующих фотохромных материалов является термиче-

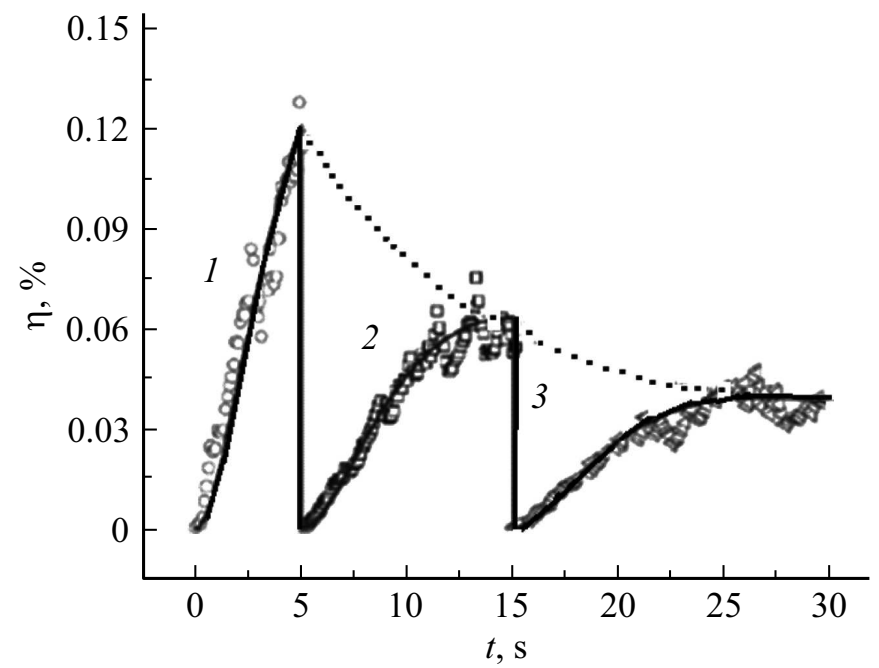

Рис. 6. Зависимость ДЭ голографических решеток от экспозиции при последовательной записи трех голограмм на одном и том участке регистрирующей среды, включающей ПММА и спирооксазин XVI [114].

ская нестабильность регистрируемых голограмм вследствие спонтанного исчезновения фотоиндуцированного окрашенного состояния, которое использовалось для записи голограмм излучением гелий-неонового лазеpa [112].

Подобными свойствами обладают фотохромные материалы, изготовленные с использованием фотохромного спирооксазина XVI, испытывающего обратимые превращения, подобные спиропиранам [113].

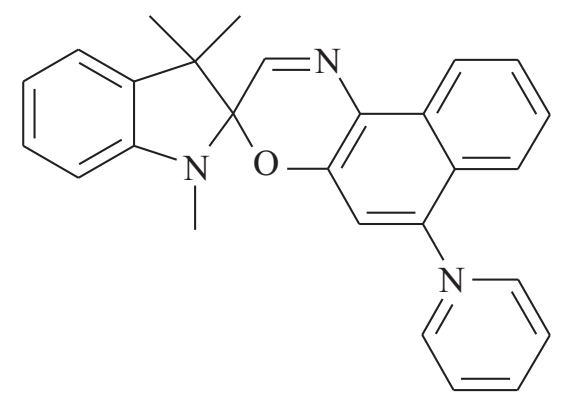

XVI

Для регистрации голограмм в ПММА слоях, содержащих это соединение, применялось лазерное излучение с длиной волны $\lambda=405 \mathrm{~nm}$. Восстановление голограмм осуществлялось светом гелий-неонового лазера $(\lambda=633 \mathrm{~nm})$. ДЭ регистрируемых голограмм достигала $2 \%$. При регистрации нескольких голограмм на одном и том же участке регистрирующей среды лазерным излучением с длиной волны $\lambda=633 \mathrm{~nm}$ при восстановлении голограмм излучением с длиной волны $\lambda=532 \mathrm{~nm}$ величина ДЭ была меньше $(0.12 \%)$ и снижалась по мере увеличения числа регистрируемых голограмм (рис. 6) [114]. 


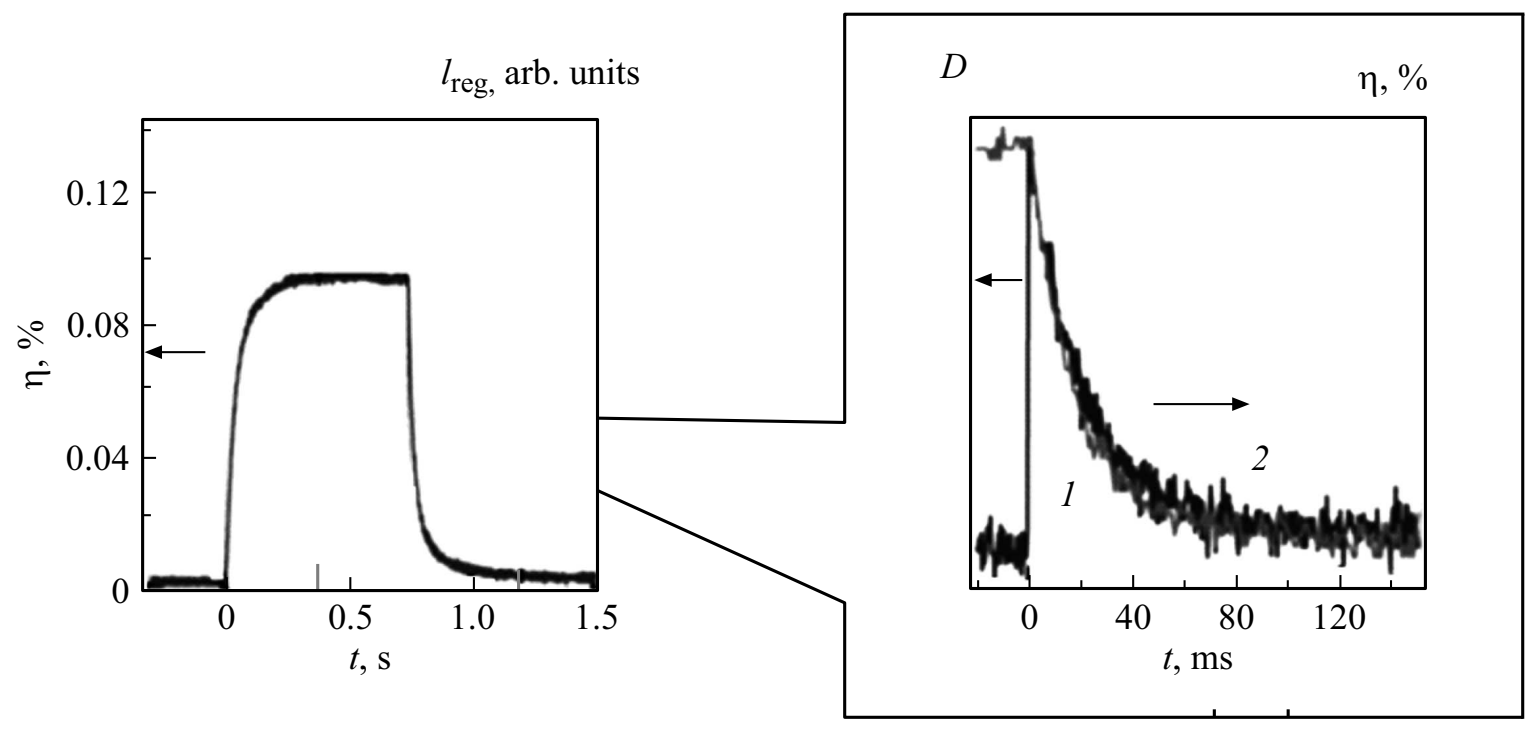

Рис. 7. Кинетика записи и темновой релаксации голограмм (1) и оптической плотности фотоиндуцированной формы (2) при использовании лазерного излучения с $\lambda=355 \mathrm{~nm}$, длительностью импульса $5 \mathrm{~ns}$ и энергией $3 \mathrm{~mJ}$ [116].

Голограммы регистрировались также в полимерных слоях, состоящих из смеси поливинилового спирта и желатины и содержащих природное фотохромное соединение - бактериородопсин [115].

Термическая нестабильность голограмм, регистрируемых в полимерных слоях на основе упомянутых выше спиросоединений и бактериородопсина, является обстоятельством, осложняющим их применение в голографии. Однако термически релаксирующие фотохромные биимидазодилы XVII, характеризующиеся времени жизни фотоиндуцированной формы около десятков миллисекунд (рис. 7), могут представлять практический интерес для динамической голографии [116]. В качестве полимерного связующего в таких средах использовалась смесь полиэтил- и полифеноксиэтилакрилаты.
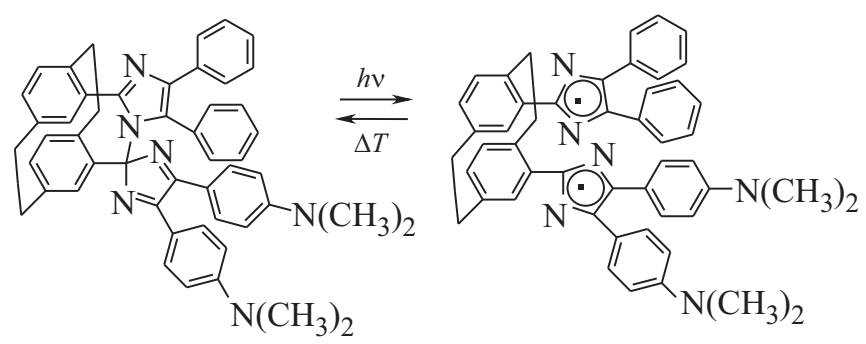

XVII

Для практической голографии наибольший интерес представляют полимерные регистрирующие среды на основе термически необратимых фотохромных соединений из классов диарилэтенов XVIII (схема 4) и фульгимидов XIX (схема 5), которые испытывают взаимные обратимые превращения между формами $A$ и $B$ только под действием света.

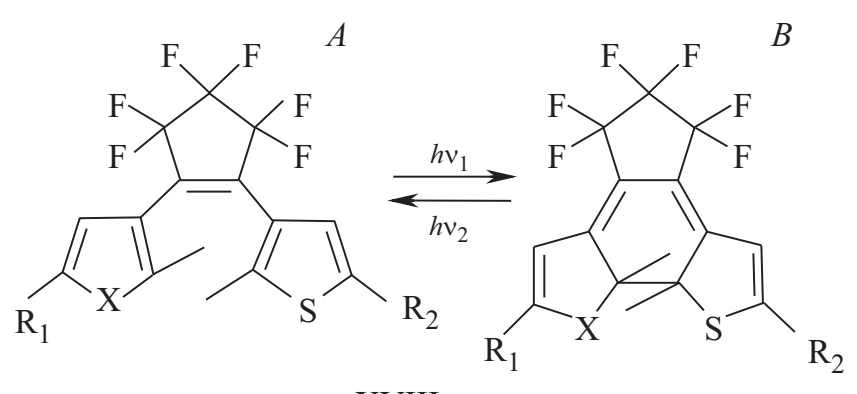

XVIII

Scheme 4<smiles>Cc1c2c(c(C)c3c1c1ccccc1n3C)C(=O)N(Cc1ccccc1)C2=O</smiles><smiles>[Y10]C1=C2C(=O)N(Cc3ccccc3)C(=O)C2=C(C)C12N(C)c1ccccc1C2(C)C</smiles>

Scheme 5

Синтезирован ряд несимметричных производных диарилэтенов и на их основе получены ПММА слои, обеспечивающие запись нескольких поляризационных голограмм на одном и том же участке регистрирующего слоя [117-123]. Показано, что слои ПММА, содержащие 1,2-бис (2,4-диметил-5-фенил-3-тиенил)-3, 3, 4, 4, 5, 5-гексафтор-1-циклопентан, обеспечива- 
ют высокую информационную емкость за счет записи голограмм диаметром $1.15 \mu \mathrm{m}$ с интервалом между ними $8.16 \mu \mathrm{m}[124]$.

С использованием молекул фотохромного диарилэтена создан голографический фотохромный полимерный материал XX, в котором фотохромные молекулы использовались в качестве полимерных фрагментов [125].<smiles>[X]c1cc(-c2ccc(Oc3c(F)c(F)c(F)c(-c4nnc(-c5c(F)c(F)c(Oc6ccc(C(C)(C)C)cc6)c(F)c5F)o4)c3F)cc2)cc(CC=C)c1OC(C)(C)C</smiles>

Запись и считывание голограмм осуществлялись лазерным излучением с $\lambda=532 \mathrm{~nm}$, а стирание голограмм - некогерентным УФ излучением с $\lambda=320 \mathrm{~nm}$. При этом фотоиндуцированное изменение показателя преломления на длине волны регистрации голограммы составляло $\Delta n=2 \cdot 10^{-4}$. В слое толщиной $320 \mu \mathrm{m}$ регистрировались голограммы с $\eta=3.8 \%$ и угловой селективностью $0.1^{\circ}$ (рис. 8 ).

Фотохромный полимер характеризуется высокой устойчивостью к необратимым фотохимическим превращениям (рис. 9).

Высокая угловая селективность регистрации объемных голограмм в слое толщиной $320 \mu \mathrm{m}\left(0.17^{\circ}\right)$ и практически приемлемая цикличность фотохромных превращений этого полимера открывают перспективы применения таких фотохромных полимерных материалов в разработке голографических $3 D$ дисплеев, работающих в реальном времени.

Показана возможность использования ПММА слоев, содержащих термически необратимый фотохромный фульгимид XIX (схема 5), в обычной и поляризационной голографии [126]. Светочувствительность таких слоев составляет около $0.35 \mathrm{~J} / \mathrm{cm}^{2}$ при регистрации голограмм излучением гелий-неонового лазера (рис. 10). Разрешающая способность достигает $6300 \mathrm{~mm}^{-1}$.

Особое внимание уделяется разработке и применению фотохромных полимерных материалов на основе азобензола XXI, испытывающего транс-цис-фотоизомеризацию (схема 6) [112].

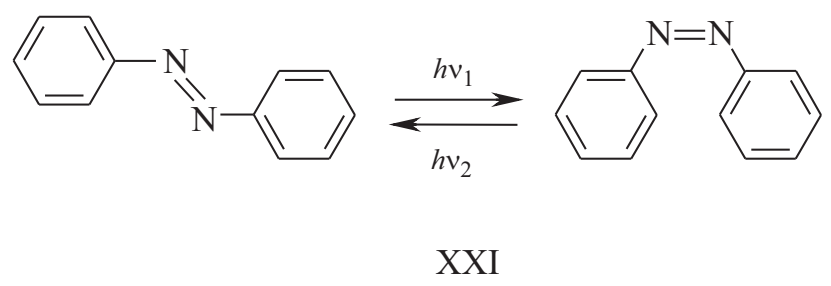

Scheme 6

С целью повышения светочувствительности фотохромных материалов на основе азокрасителей разрабо-

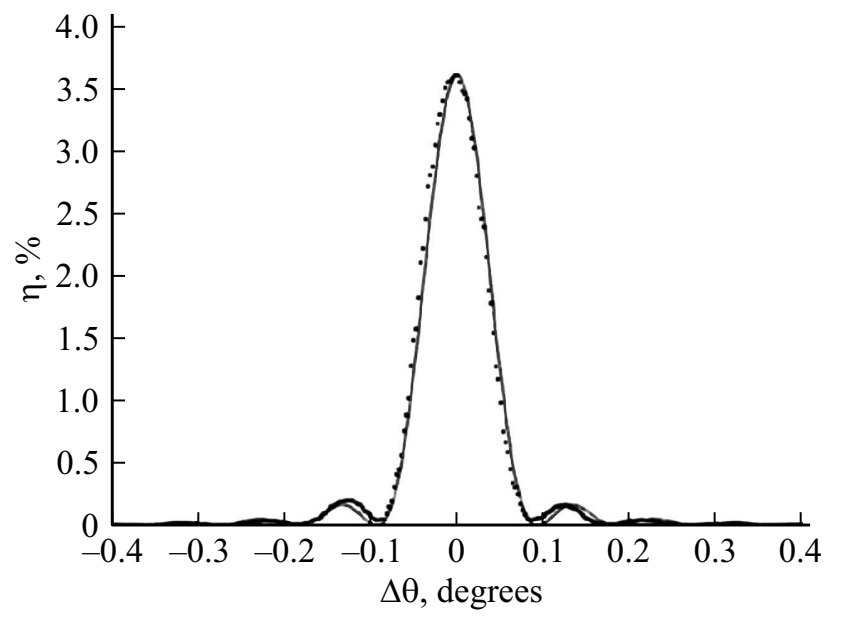

Рис. 8. Угловая чувствительность слоя фотохромного полимеpa [125].

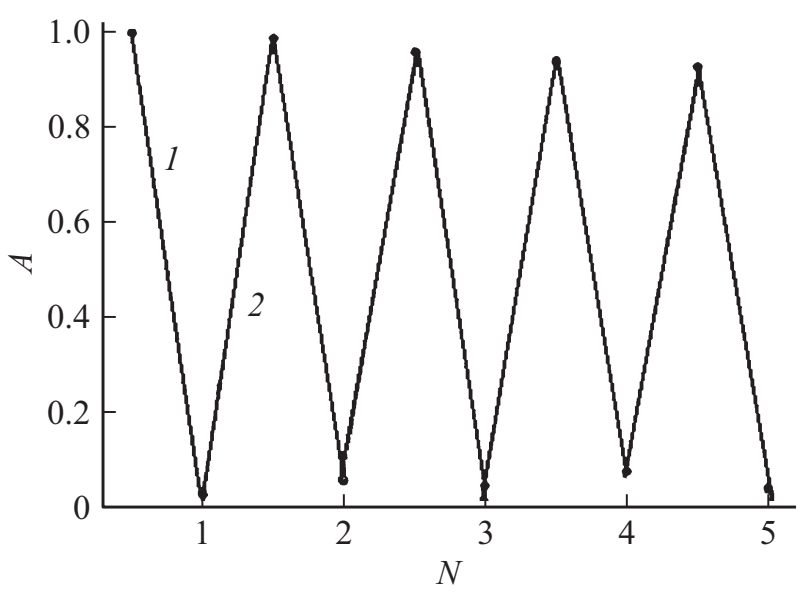

Рис. 9. Цикличность фотопревращений фотохромного полимера XX в диметилформамиде [125]: изменение оптической плотности на $532 \mathrm{~nm}$ в ходе прямых (1) и обратных (2) превращений.

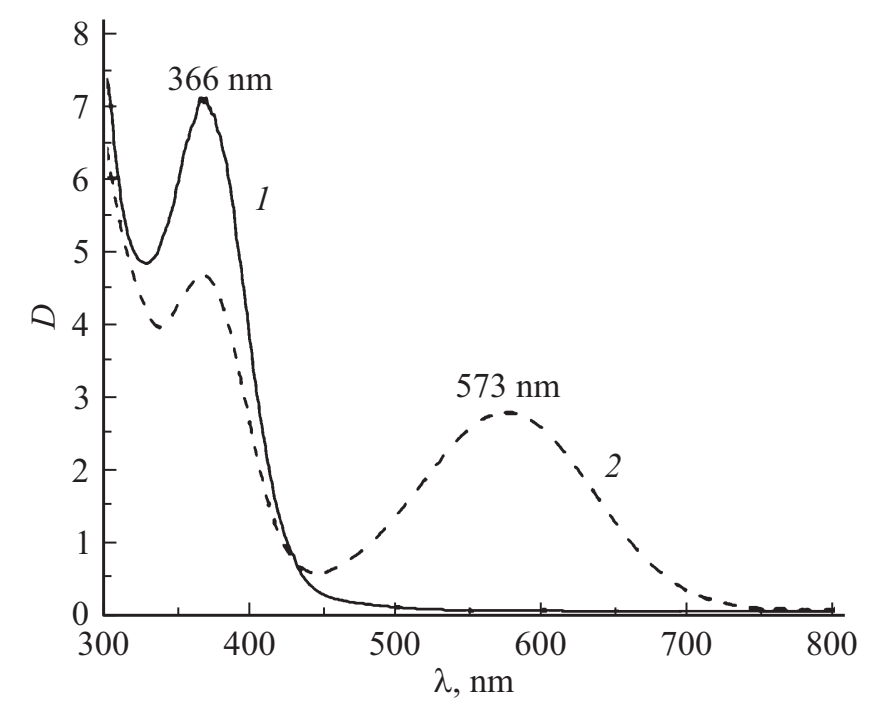

Рис. 10. Спектры поглощения фульгимида XIX в ПММА пленке до (1) и после УФ облучения (2) [126]. 
таны золь-гелевые регистрирующие среды XXII с азохромофорными фрагментами [127]. Использование промежуточных нефотохромных фрагментов обеспечивает свободную пространственно-незатрудненную фотоиндуцированную транс-цис-фотоизомеризацию и, следовательно, высокую светочувствительность таких сред. Они обладают фотоанизотропными свойствами $(\Delta n=0.11)$ и обеспечивают обратимую регистрацию голограмм с $\eta=100 \%$.

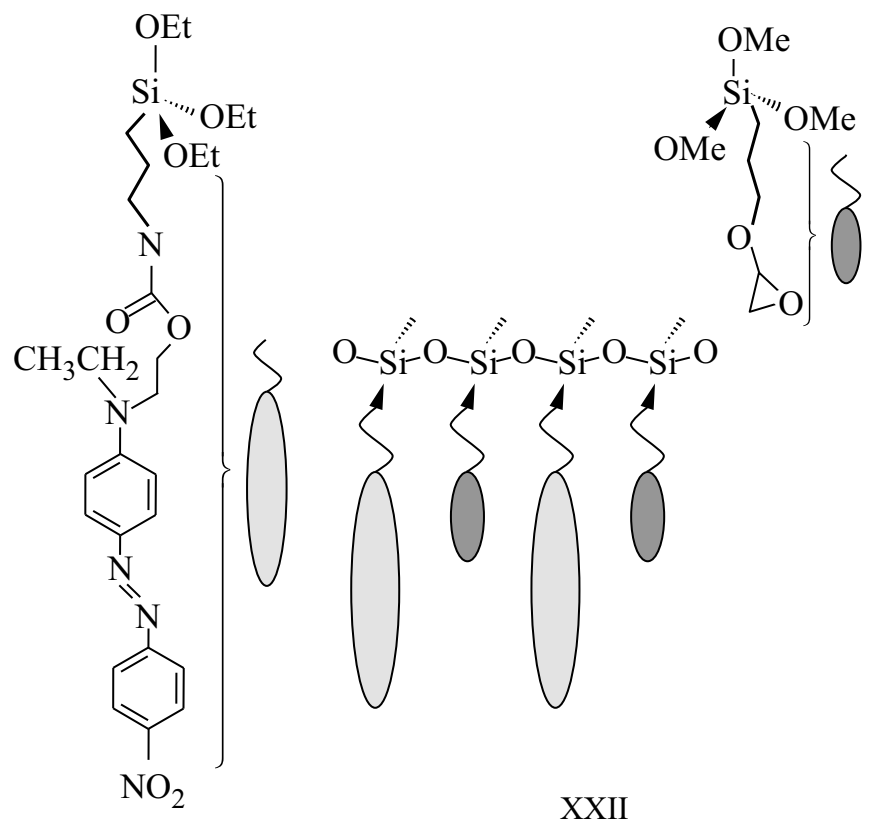

В слоях композиционного полимера, содержащего фрагменты ПММА и азокрасителя, толщиной $500 \mu \mathrm{m}$ циркулярно поляризованным импульсным (10 ms) излучением лазера с $\lambda=488 \mathrm{~nm}$ записывались поляризационные голограммы с ДЭ до $0.0035 \%$ при экспозиции $50 \mathrm{~mJ} / \mathrm{cm}^{2}$ [128]. На одном участке слоя регистрировалось до 20 поляризационных голограмм. Снижение длительности импульса до $2 \mathrm{~ms}$ приводило к повышению светочувствительности слоев азополистирольных полимеров до $4 \mathrm{~mJ} / \mathrm{cm}^{2}$ и возрастанию величины ДЭ до $0.005 \%$ [129]. При этом было обнаружено, что ДЭ голограмм и их термическая стабильность зависят от предварительного облучения слоя излучением с $\lambda=488 \mathrm{~nm}$, интенсивности считывающего излучения с $\lambda=633 \mathrm{~nm}$ и промежутка времени между окончанием предварительного облучения и воздействием импульсного регистрирующего излучения. В результате исследования были определены оптимальные условия регистрации поляризационных голограмм [130].

Детальное исследование эффективности фотоанизотропии водорастворимых азокрасителей в зависимости от компонентного состава регистрирующей среды показало, что она возрастает при ионном взаимодействии между азокрасителем и полимером, в частности поливи- нипирролидоном XXIII [131].

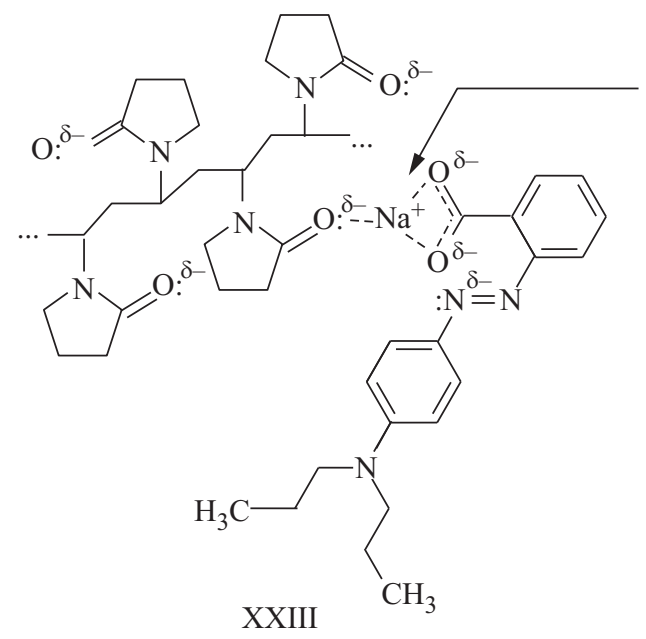

Наибольшие величины фотоиндуцированных двулучепреломления $\left(\Delta n=1 \cdot 10^{-2}\right)$ и дихроизма $(D=0.36)$ наблюдались для азобензолсодержащих ионных комплексов XXIV [132].<smiles>CCCC[n+]1ccc(C(CC(C)(C)C)C(C)(C)CC(C)(C)C(CC(C)(C)C)c2ccc(S(=O)(=O)c3ccc(N=Nc4ccc(N(C)C)cc4)cc3)cc2)cc1</smiles>

Наибольшую эффективность фотоанизотрапии проявляет бис-азокраситель XXV с 4 ионными центрами взаимодействия. В качестве полимерного связующего наиболее эффективным оказалось использование высокополярных, в частности эпоксидных полимеров.<smiles>[X][X]#N</smiles>

Регистрация поляризационных голограмм возможна в полимерных слоях на основе азобензолсодержащих 


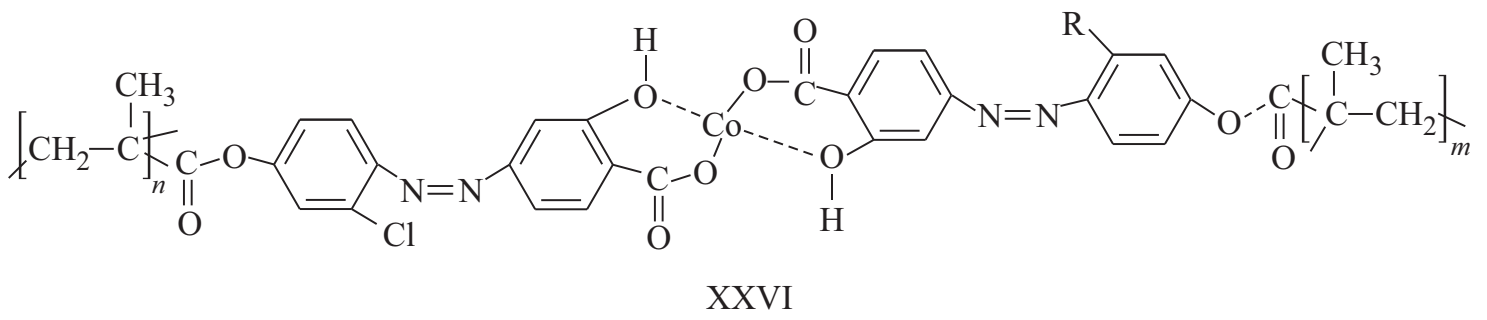

поликомплексов XXVI с координационными металлами, которые обладают повышенной светочувствительностью при наложении внешнего электрического поля [133].

Результаты исследования явления фотоанизотропии в азополимерах показали, что это явление обусловлено двойным лучепреломлением, возникающим в результате не только линейной, но и вращательной поляризации молекул в слое [134].

Для повышения светочувствительности фотоанизотропных систем на основе азополимеров в состав слоя вводят разветвленное соединение XXVII или XXVIII, содержащее три молекулы азокрасителя в едином блоке [135]. Эти соединения выполняют функцию пластификаторов, увеличивая свободный молекулярный объем, и тем самым повышают эффективность цис-транс-фотоизомеризации полимерных фрагментов азокрасителей.

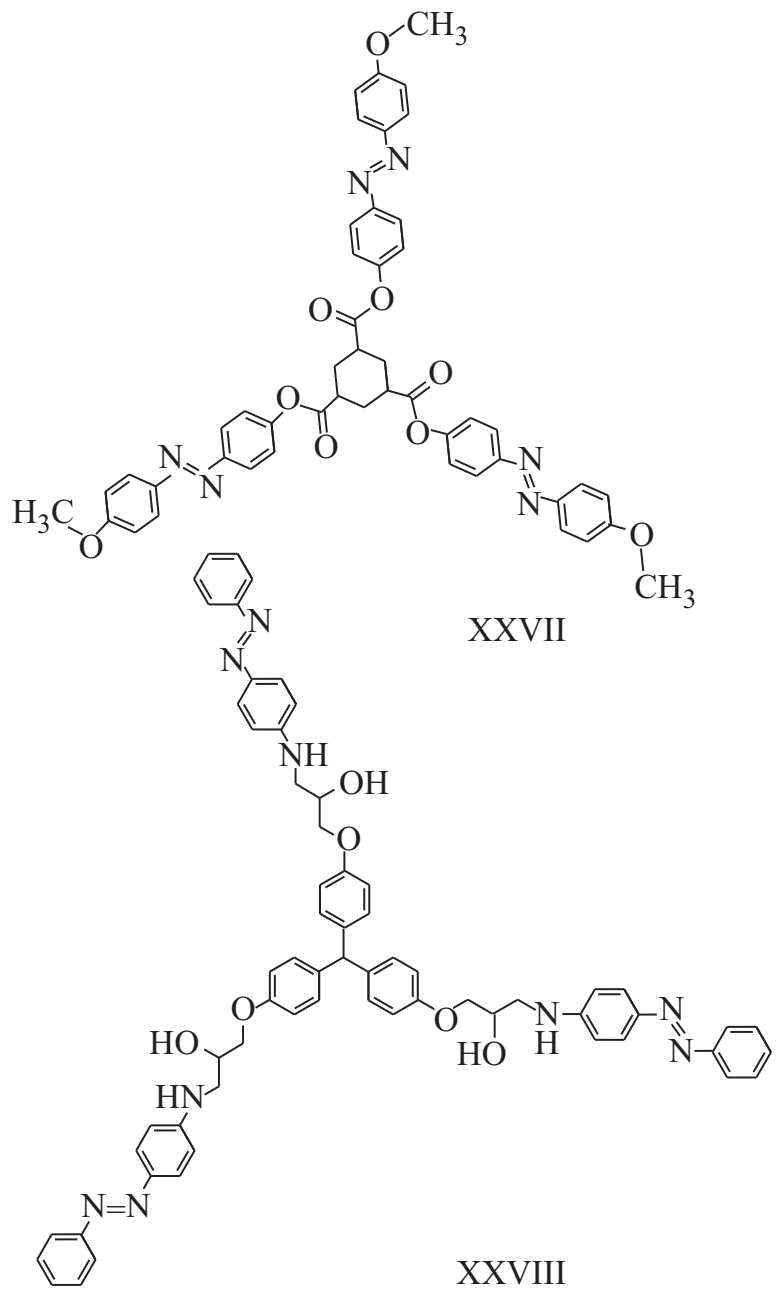

Проведено сравнительное исследование голографических свойств ряда подобных азобензолсодержащих молекул XXIX-XXXII [136].<smiles>[X][X]#[X]C([X])=O</smiles>

XXIX XXX

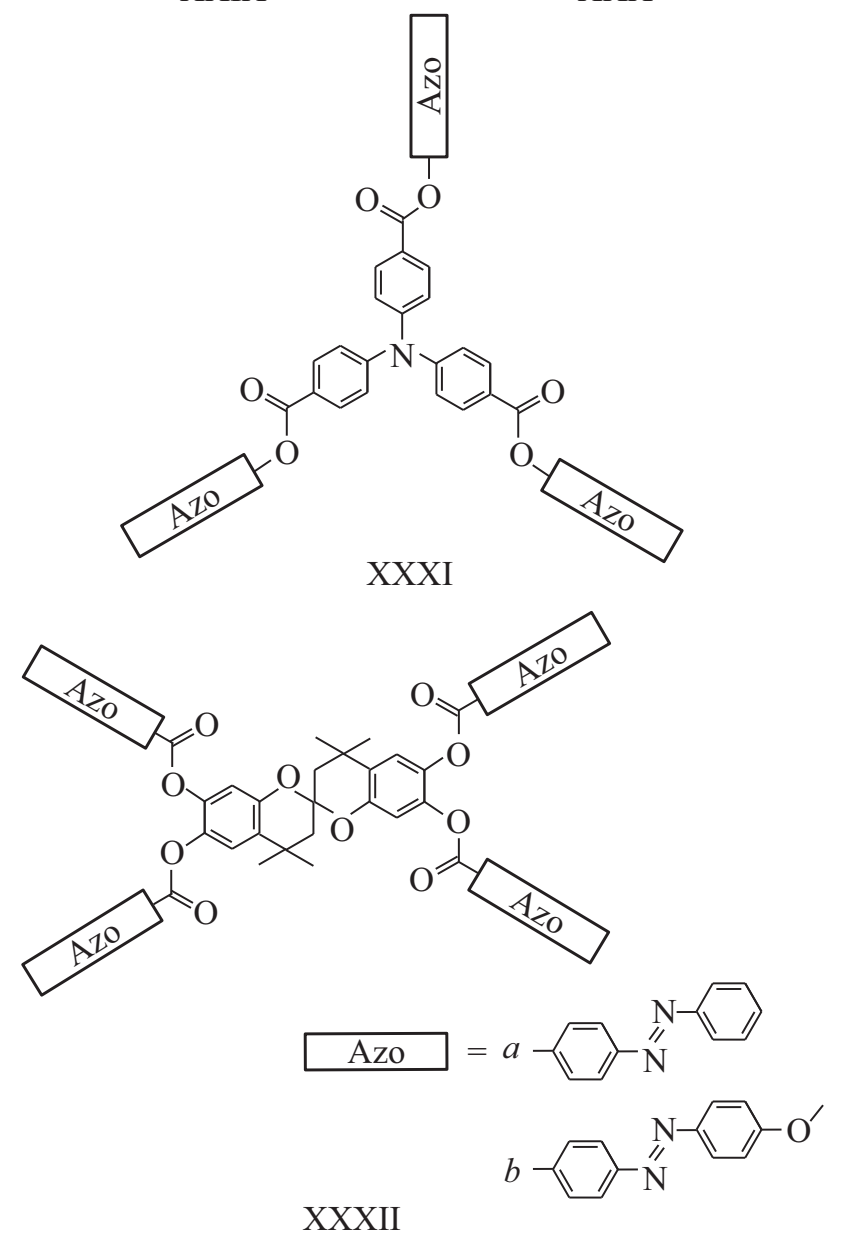

По своим характеристикам полимерные слои этих соединений незначительно отличаются от слоев на ос- 


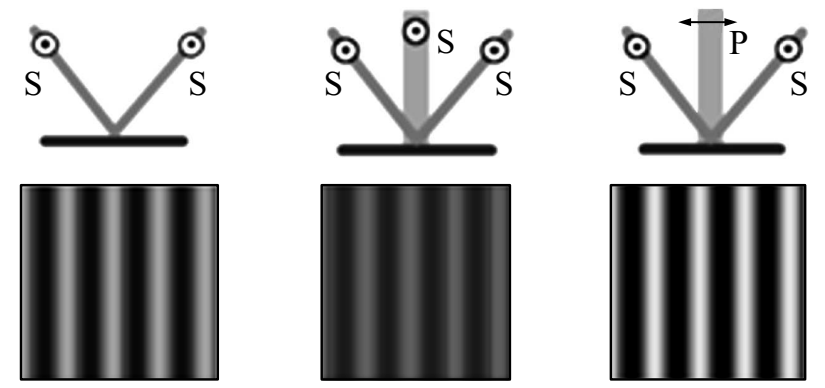

Рис. 11. Запись голограмм, регистрируемых в слоях ПММА, содержащих азокраситель, при различной поляризации третьего некогерентного пучка [137].

нове их и 50 вес.\% полистирола. Большинство из них характеризуется высокой светочувствительностью, которая повышается при нагреве слоев.

Исследование молекулярно-диспергированного азокрасителя XXXIII в пленке ПММА показало, что свойства поляризационных голограмм, в частности величина ДЭ, полученных при записи двумя когерентными пучками, существенно зависят от поляризации третьего некогерентного пучка (рис. 11) [137].<smiles>CCN(CCO)c1ccc(/N=N/c2ccc([N+](=O)[O-])cc2)cc1</smiles>

XXXIII

Исследование зависимости поляризационной светочувствительности от структуры азокрасителей и кислотности растворителей, использованных при получении пленок поливинилпирролидона, показало, что величина фотоиндуцированной анизотропии определяется структурой молекулы азокрасителя и снижается с увеличением кислотности среды [138]. Величина фотоиндуцированного дихроизма при любой кислотности зависит только от асимметрии молекулярной структуры соединения XXXIV.

$$
\mathrm{R}=\mathrm{R}^{\prime}=\mathrm{N}-\left(\mathrm{CH}_{3}\right)_{2} ; \mathrm{N}_{2}-\left(\mathrm{C}_{2} \mathrm{H}_{5}\right)_{5} ; \mathrm{NH}-\mathrm{C}_{3} \mathrm{H}_{7} \text {; }
$$

\section{XXXIV}

Рельефные поляризационные голографические решетки регистрировались в низкомолекулярных азобензолсо- держащих полимерных стеклах XXXV [139].<smiles>[X]C(=O)OCCOc1cc(OCCOC(c2ccccc2)(c2ccccc2)c2ccccc2)cc(C(=O)OCCOc2cc(OCCOC(c3ccccc3)(c3ccccc3)c3ccccc3)cc(OCCOC(c3ccccc3)(c3ccccc3)c3ccccc3)c2)c1</smiles>

Стеклообразные слои на основе производного метоксиаминотриазин замещенного азобензола XXXVI обеспечивают регистрацию термически стабильных голографических решеток с $\eta>45 \%$ [140].<smiles></smiles>

Для регистрации рельефных голографических элементов без проявления предлагается использовать слои 4-((4-(бис(5,5,5-трифенилпентил)амино(фенил)диазенил) бензойной кислоты XXXVII [141]. Правда, эти слои характеризуются низкой светочувствительностью. Голограммы с $\eta=20 \%$ регистрируются при экспозициях $60 \mathrm{~J} / \mathrm{cm}^{2}$.

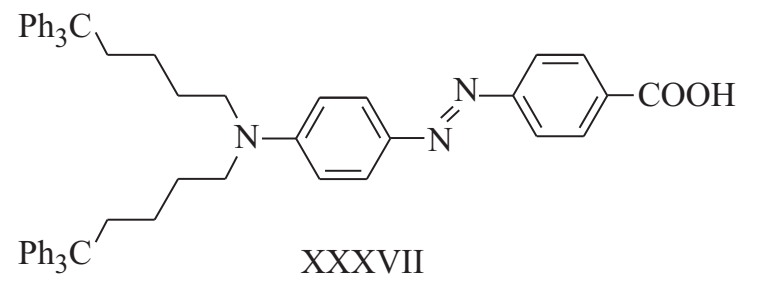

Поляризационные рельефные голографические решетки регистрировались также в слоях азополимера XXXVIII. Введение наночастиц $\mathrm{ZnO}$ или $\mathrm{SiO}_{2}[142-145]$ в состав позволило увеличить ДЭ и высоту рельефа голографических решеток.<smiles>[X][R]C([R])=[W]</smiles> 
Рельеф поляризационных голографических решеток, зарегистрированных в слоях полимера XXXIX, превышал в 3 раза толщину полимерного слоя [146].

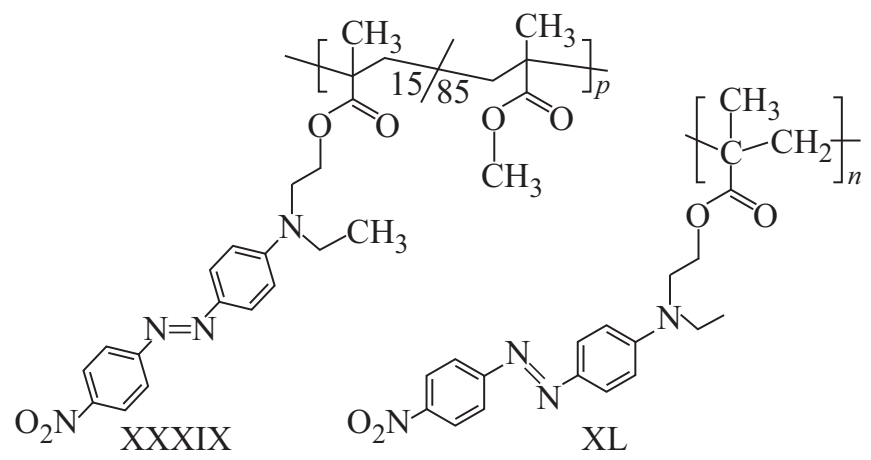

Рельефные голографические решетки высокого качества были получены в слоях азобензол-содержащих эпоксидных смол XL [147]. Регистрация рельефных и объемных поляризационных голограмм возможна в желатиновых пленках, содержащих азокраситель [148].

Показана возможность использования слоев блочного полимера XLI, включающего полистирольную матрицу (77.5 вес.\%), азобензольные $(8.4$ вес.\%) и мезогенные цепи (12.3 вес.\%), гидроксиэтилметакрилат (1.8 вес.\%), для записи-стирания более 80 голограмм на одном участке регистрирующего слоя под разными углами [149].

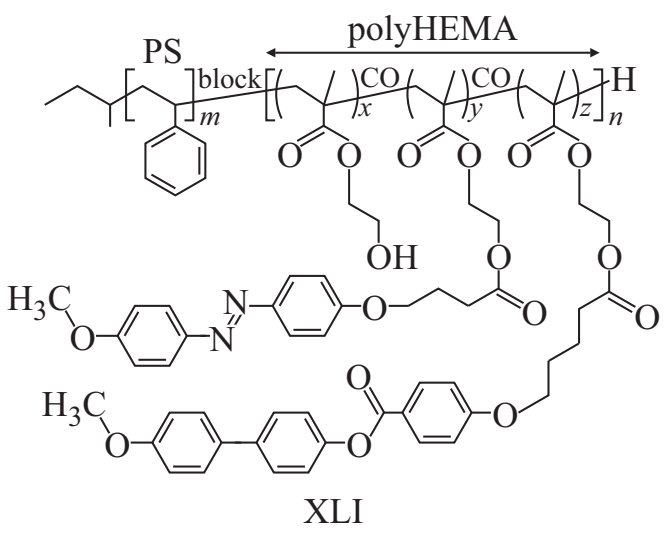

Эти слои допускают большое число циклов записистирания (рис. 12), но характеризуются низкой светочувствительностью $\left(250 \mathrm{~J} / \mathrm{cm}^{2}\right)$.

C использованием полимера XLII, содержащего азобензольные фрагменты, изучена зависимость релаксационного усиления ДЭ рельефных голограмм, зарегистрированных в слоях этого полимера [150]. Показано, что при температуре стеклования массоперенос снижается и, как следствие, усиление ДЭ голограмм затрудняется.

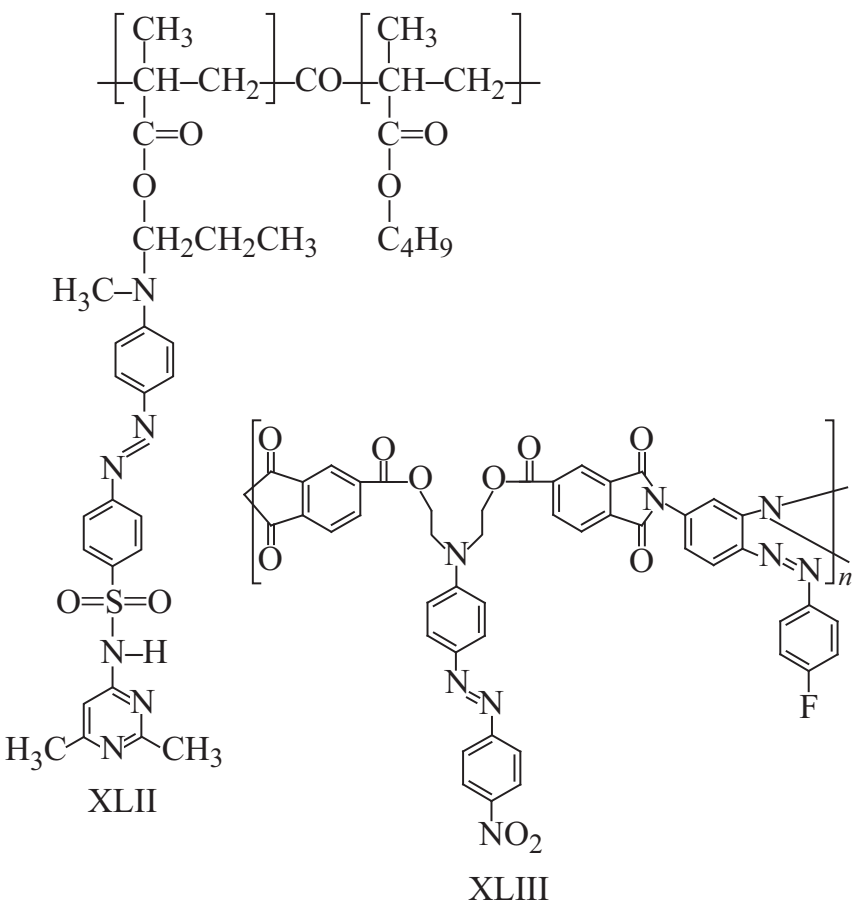

Для азобензол-содержащего полимера XLIII показана возможность повышения в 2 раза величины ДЭ и в 3 раза амплитуды рельефных голограмм (рис. 13) путем регистрации голограмм излучением с $\lambda=532 \mathrm{~nm}$ в присутствии лазерного излучения с $\lambda=405 \mathrm{~nm}$ [151].

Для получения люминесцирующих голографических решеток использовались металлоорганические азополимеры XLIV, содержащие комплексы с редкоземельными элементами [152].

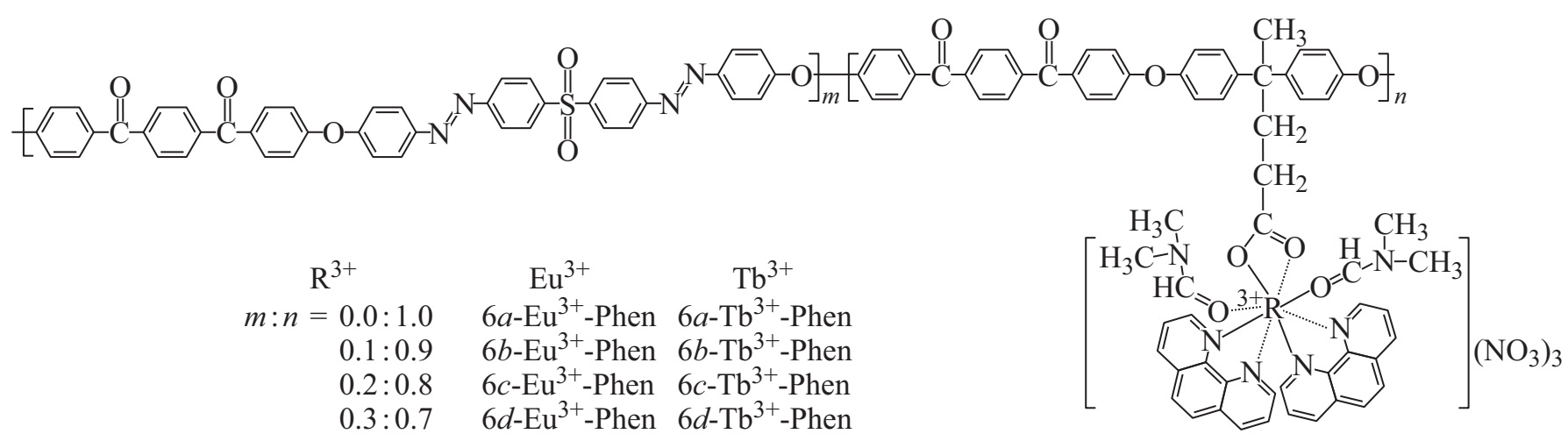




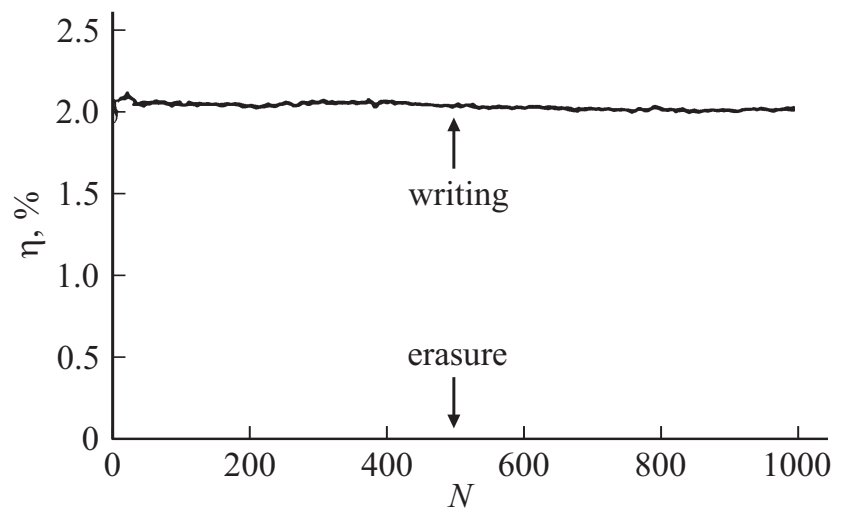

Рис. 12. Цикличность фотохромных превращений блочного фотохромного полимера XLI при использовании лазерного излучения с $\lambda=514 \mathrm{~nm}$ с взаимноперпендикулярной поляризацией пучков [149]: зависимость ДЭ после записи и стирания от числа пройденных циклов.
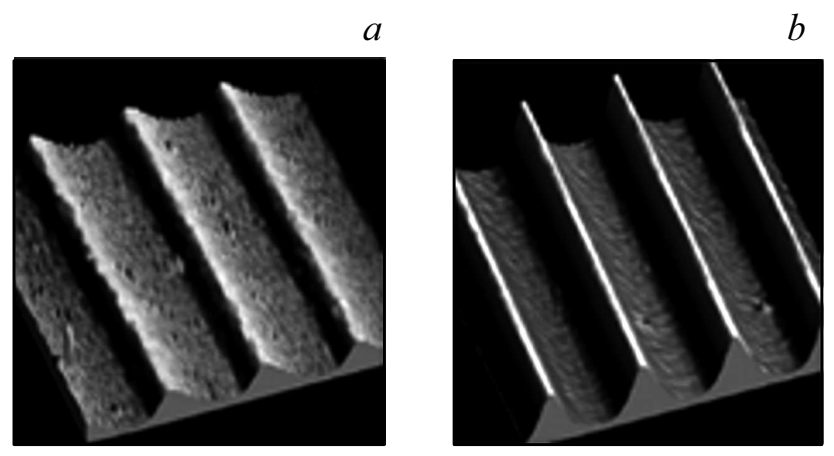

Рис. 13. Фотографии голографических дифракционных решеток, зарегистрированных в азобензол-содержащем полимеpe XLIII лазерным излучением с $\lambda=532 \mathrm{~nm}$ без (a) и в присутствии $(b)$ лазерного излучения с $\lambda=405 \mathrm{~nm}[151]$.

Применение фотополимеризующихся композиций, в состав которых включается азокраситель, испытывающий транс-цис-фотоизомеризацию, позволяет создавать необратимые фотонные структуры в виде объемных решеток и двумерных фотонных гексагональных кристаллов, а также обратимые фотопереключатели, свойства которых определяются транс-цис-фотоизомеризацией азокрасителя, находящегося в объеме заполимеризованного стекла [153].

Пленки ПММА с молекулярно диспергированным азокрасителем применялись для регистрации и исследования свойств бегущих голограмм [154]. В отличие от фоторефрактивных материалов полимерные слои с азокрасителем, испытывающим цис-транс-фотоизомеризацию, обеспечивали усиление сигналов в оптическом диапазоне без применения электрического напряжения [155]. При этом светочувствительность составляла $0.01 \mathrm{~J} / \mathrm{cm}^{2}$.

С использованием азополимера XLV, обладающего равными эффективностями линейной и циркулярной поляризаций, показана возможность создания дифракционного линейного поляризатора, который разделяет падающий пучок света на два с ортогонально поляризованными компонентами [156].<smiles>CCC(C)C(=O)OCc1cn(CCOC(=O)C(C)(COC(=O)CCCOc2ccc(N=Nc3ccc(C#N)cc3)cc2)COC(=O)NCCOc2ccc(-c3ccc(C#N)cc3)cc2)nn1</smiles>

\section{2. Светочувствительные ЖК полимерные системы}

Жидкие кристаллы (ЖК) обладают высокой оптической прозрачностью, проявляют эффективное двойное лучепреломление, меняют свою ориентацию под действием света и электрического поля, что делает их весьма привлекательными для создания регистрирующих сред для статической и динамической голографии [157].

Регистрация поляризационных голограмм возможна в полимерных ЖК системах, в которых молекулы азобензола химически связаны с полимерной матрицей, а молекулы нематических ЖК находятся в свободном молекулярном объеме [158].

Среди синтезированных двухблочных полимеров, содержащих азобензольные и ЖК холестерические фрагменты, наиболее сильное двойное лучепреломление обнаружено для соединения XLVI с наибольшей концентрацией азобензольных фрагментов $(\Delta n=0.036)$ [159].

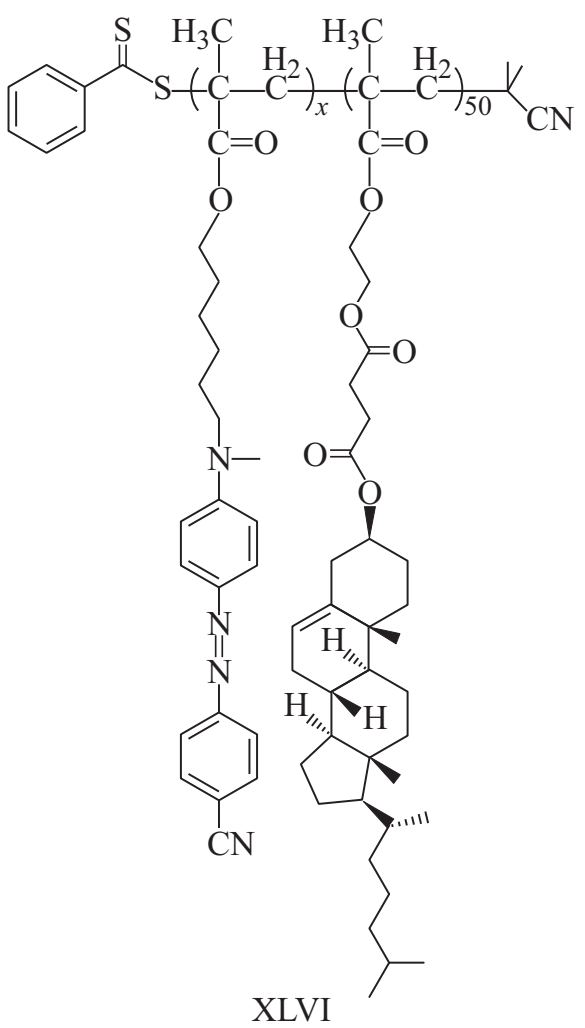

ЖК полимер XLVII на основе азобензольной структуры обеспечивает регистрацию амплитудных и поляризационных голографических решеток с ДЭ до 30\% [160]. 


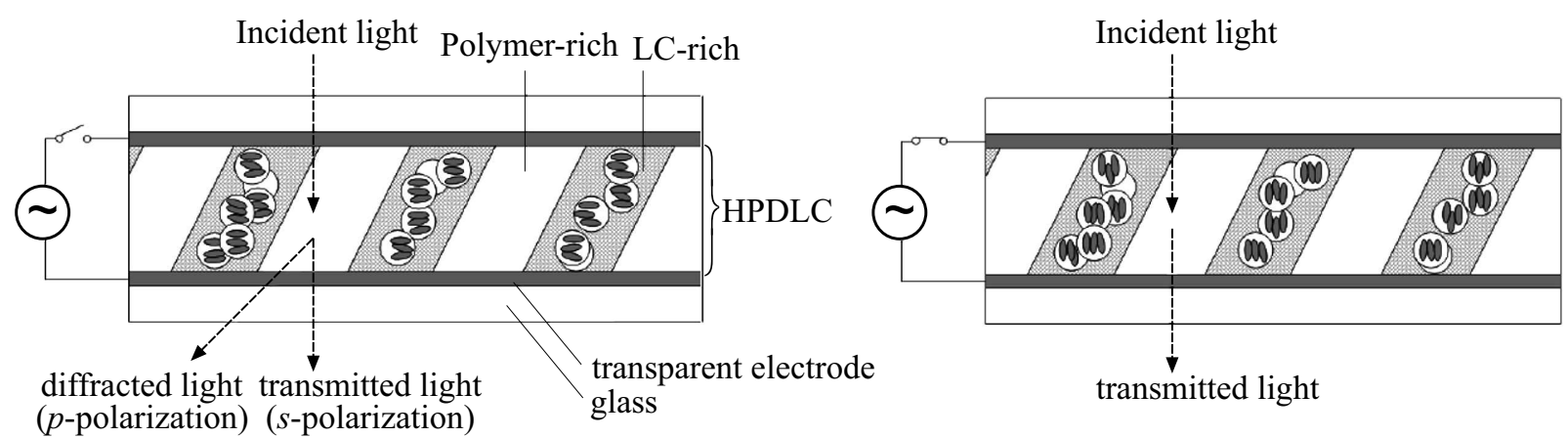

Рис. 14. Схема работы ГОЭ на основе ЖК и фотополимера без $(a)$ и в присутствии $(b)$ электрического поля [168].

В случае поляризационных решеток величина ДЭ зависит от поляризации считывающего луча. Высокая величина ДЭ обусловлена цис-транс-фотоизомеризацией азобензола и фотоориентацией ЖК фрагментов.

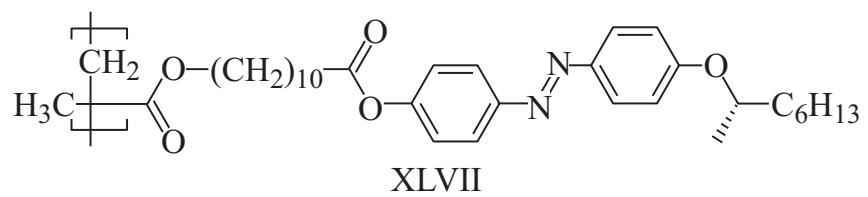

Одним из перспективных методов формирования голографических решеток в средах, содержащих ЖК, является фазовое разделение в системах фотополимеризующаяся система-ЖК [161]. Материалы этого типа основаны на фотоориентации ЖК в полимерно-мономерной системе, содержащей краситель, поглощающий лазерное излучение. После записи голограмм эта регистрирующая среда стабилизировалась путем облучения некогерентным УФ облучением. Свойства таких сред могут изменяться не только под действием лазерного излучения, но и под влиянием электрического поля [162].

Для регистрации объемных голограмм в фотополимеризующейся среде, содержащей ЖК, использовалась фотоинициирующая система, включающая Бенгальскую Розу XLVIII и N-фенилглицин XLIX [163]. Фотоинициирующие свойства последнего компонента и ингибирующие функции первого компонента этой системы позволяли регистрировать голограммы с $\eta=87 \%$.<smiles>Cc1c(I)cc2c(-c3c(Cl)c(Cl)c(Cl)c(Cl)c3C(=O)O)c3cc(I)c(=O)c(I)c-3oc2c1I</smiles>

XLVIII<smiles>O=C(O)CNc1ccccc1</smiles>

XLIX
В подобной фотополимеризующейся регистрирующей среде на основе акриловых композиций и нематических ЖК, в которой вместо Бенгальской Розы использовался другой краситель - 3, 3'-карбонилбис(7- диэтиламинокумарин) L, зарегистрированы цветные голограммы, восстанавливаемые некогерентным белым светом [164].<smiles>CCNc1ccc2cc(C(=O)c3cc4cc([I+])ccc4oc3=O)c(=O)oc2c1</smiles>

$\mathrm{L}$

С использованием полимерных материалов, содержащих ЖК и Бенгальскую Розу в качестве фотосенсибилизатора, показана возможность создания голографических светочувствительных сред, содержащих многослойные нанотрубки и проявляющих электрооптические свойства [165].

Полимерные фотосшивающиеся слои, содержащие молекулы азобензола с метакрильными заместителями и ЖК, обеспечивают регистрацию термически стабильных голограмм и их недеструктивное восстановление [166].

Замена пентаэритритолакрилатных светочувствительных композиций на уретанакрилатные позволяет регистрировать голографические решетки с $\eta=90.3 \%$ c переключением при электрическом напряжении $E=11-27 \mathrm{~V}[167]$

ЖК фотополимеризующиеся композиции на основе производных полипропиленгликоля, функционализированных метакрилатными и силоксановыми фрагментами, использовались для получения ГОЭ с электрическим переключением (рис. 14) [168]. При получении голографической решетки в такой композиции молекулы ЖК вытесняются в необлученные участки интерференционной картины. После некогерентного УФ облучения голограмма сохраняется неизменной. Электрическое поле позволяет, воздействуя на молекулы ЖК, изменять интенсивность проходящего света.

ДЭ голографических решеток может управляться также ультразвуковым излучением [169]. С увеличением интенсивности ультразвука величина ДЭ голограмм падает вследствие перестройки ЖК молекул.

Полимерные слои с диспергированными в них ЖК могут использоваться для создания трехмерных дифракционных структур [170]. 
На основе эффектов фотоанизотропии азобензолсодержащих полимеров с боковыми ЖК цепями и кооперативного эффекта был создан ЖК полимерный материал для регистрирующих сред оптической памяти высокой плотности [171]. В качестве полимерной основы использовался полиметилгидросилоксан LI с боковыми цепями светочувствительного производного азобензола LII и ЖK LIII. Кроме того, в состав материала входил сшивающий агент LIV. Оказалось, что такие слои проявляют фотомеханический эффект.

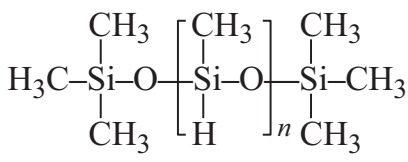

$$
\begin{aligned}
& \left(M_{n}=4000, M_{w} / M_{n}=1.5\right)
\end{aligned}
$$

LI<smiles>COc1ccc(/N=N/c2ccc(OC)cc2)cc1</smiles><smiles>COc1ccc(OC(=O)c2ccc(OC)cc2)cc1</smiles><smiles>C=COc1ccc(OC=C)cc1</smiles>

LIV

Исследование свойств ферроэлектрических ЖК LV-LVII, содержащих в своем составе, кроме фотосенсибилизатора LVIII, фотопроводящее хиральное соединение LIX, показало, что при регистрации голограмм с $\eta=1-2 \%$ лазерным излучением с $\lambda=488 \mathrm{~nm}$ при наложении электрического напряжения до $2 \mathrm{~V} / \mu \mathrm{m}$ наблюдался значительный фоторефрактивный эффект, обеспечивающий визуализацию голограмм за $8 \mathrm{~ms}$ [172]. Это открывает возможность создания динамических $3 D$ дисплеев, работающих в реальном масштабе времени.

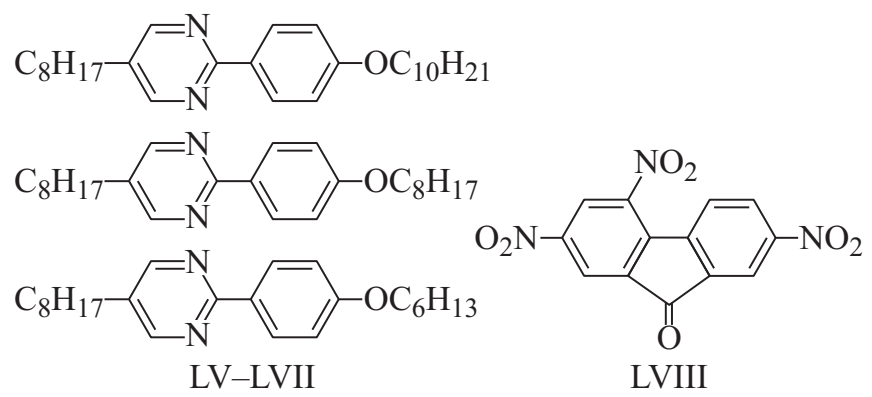<smiles>[R14]c1ccc(-c2ccc(-c3ccc([AsH2])s3)s2)s1</smiles>

Полимерные слои, содержащие смесь нематического ЖК с фотохромными азофрагментами LX и хиральной фотохромной добавки LXI, позволяют на одном и том же материале записывать изображение некогерентным УФ излучением и голографические решетки излучением аргонового лазера $(\lambda=488 \mathrm{~nm})[173]$.<smiles>COc1ccc(C(=O)Oc2ccc(OC(=O)CCCCCOC(=O)C3CC(C)CC(C(=O)O)CC3C(=O)O)cc2)cc1</smiles>

LX<smiles>[M]O[C@H]1C(OC(=O)/C=C/c2ccc(OC)cc2)[C@H]2OC[C@@H](OC(=O)/C=C/c3ccc(OC)cc3)[C@@H]21</smiles>

Тонкий слой этой холестерической пленки на стеклянной подложке с полиамидным покрытием сначала облучался УФ светом через маску, содержащую информацию, с целью получения изображения буквенноцифровой информации. Затем на том же участке регистрировалась голографическая решетка. Голограмма и буквенное изображение визуализировались излучением гелий-неонового лазера.

Фотоанизотропные материалы на основе азополимеров, содержащие ЖК, были использованы для создания фотоуправляемых линз Френеля [174].

\section{3. Фоторефрактивные полимерные материалы}

Механизм записи голограмм за счет фоторефрактивного эффекта, как известно, основан на генерации заряда под действием лазерного излучения в присутствии сенсибилизатора и его перераспределении, вызывающим модуляцию показателя преломления.

Фоторефрактивные органические регистрирующие слои появились в 1991 г. через 40 лет после открытия фоторефрактивных свойств нелинейно-оптических неорганических кристаллов. Оказалось, что они обладают рядом преимуществ, а именно низкой себестоимостью, простотой изготовления элементов оптических устройств, возможностью получения элементов больших размеров, низкой диэлектрической проницаемостью, легкостью введения добавок различного типа для управления электрической проводимостью, оптической нелинейностью и свойствами по захвату заряженных частиц [175]. Фоторефрактивные полимеры превосходят кристаллы по величине ДЭ регистрируемых голограмм, усилению связанных лазерных пучков и светочувствительности. 
Для реализации практических задач был получен ряд важных результатов [175]. С целью снижения температуры стеклования и повышения скорости перемещения зарядов получены новые полимерные транспортные слои с бис-триариламинными боковыми звеньями. Синтезирован ряд эффективных сенсибилизаторов. Разработаны слои с чувствительностью в ИК спектральном диапазоне, в том числе к импульсному лазерному излучению с частотой 100 Гц. Хорошими свойствами обладает поливинилкарбазол (ПВК) и его производные [176]. Однако среды на их основе характеризуются низкой подвижностью дырок и высокой температурой стеклования $\left(T_{g}>200^{\circ} \mathrm{C}\right)$. Наиболее приемлемы регистрирующие среды, которые обеспечивают получение голограмм с высокой ДЭ, быстрым фотоответом при низком напряжении электрического поля.

В слоях азобензола LXII с донорными трифенилметановыми фрагментами, поглощающими в видимой области спектра (450-650 nm), могут регистрироваться голограммы с $\eta>20 \%$ при эффективности нелинейно оптического отклика $d_{33}=125.7 \mathrm{pm} / \mathrm{V}$ [177].

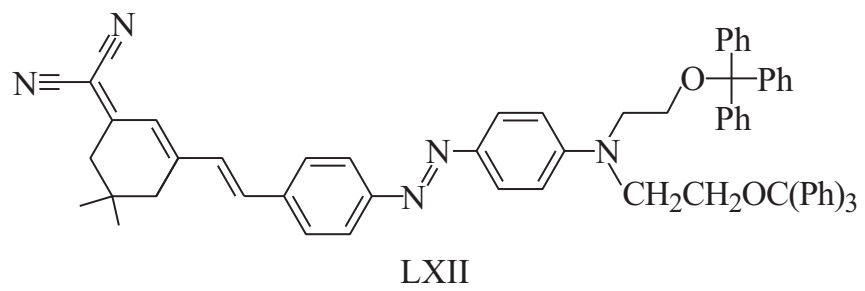

Полимерные композиты, в состав которых входят ПВК LXIII, краситель с нелинейностью второго порядка - малонитрил 4-азациклогептилбензилидена LXIV, карбозалилэтилпропионат LXV, используемый в качестве фотопроводящего пластификатора, и сенсибилизатор 2,4,7-тринитро-9-флуоренон LXVI, обеспечивают регистрацию голограмм с $\eta=68 \%$ при $E=45 \mathrm{~V} / \mu \mathrm{m}$ лазерным излучением с длиной волны $\lambda=522 \mathrm{~nm}$ при восстановлении излучением с длиной волны $\lambda=642 \mathrm{~nm}$. Регистрация и восстановление голограмм осуществлялись в реальном времени, в том числе с использованием промежуточного динамического транспаранта.<smiles>CCC(CC)n1c2ccccc2c2ccccc21</smiles>

LXIII<smiles>CCC(=O)OCCn1c2ccccc2c2ccccc21</smiles>

LXV<smiles>N#CC(C#N)=Cc1ccc(N2CCCCCC2)cc1</smiles>

LXIV<smiles>O=C1c2cc([N+](=O)[O-])ccc2-c2c1cc([N+](=O)[O-])cc2[N+](=O)[O-]</smiles>

LXVI
Благодаря проведенным исследованиям [178,179] был разработан новый композитный материал, состоящий из

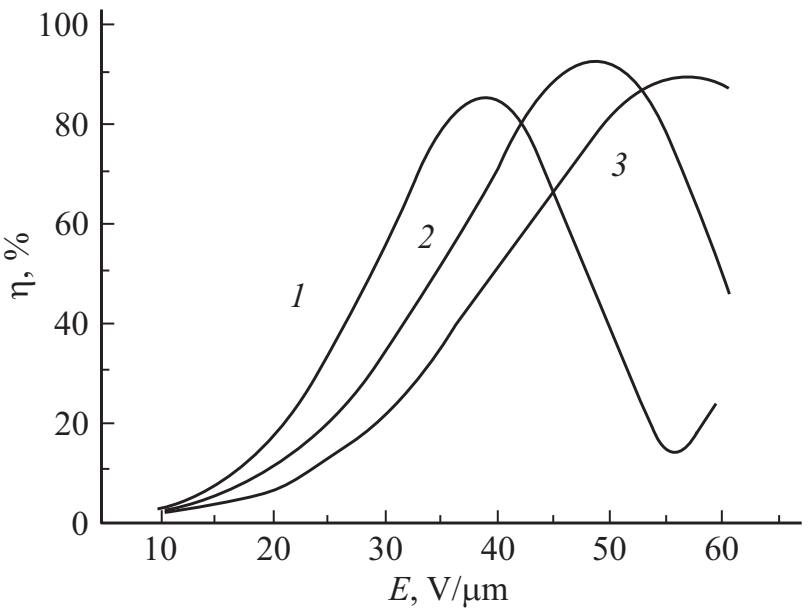

Рис. 15. Зависимость величины ДЭ голограмм от приложенного электрического поля на длинах волн $\lambda=532$ (1), 561 (2), $594 \mathrm{~nm}(3)$ [180].

фотопроводящего полимера - поли (4-дифениламино) бензил акрилата LXVII, фенил-С 61 метилэфира бутирильной кислоты LXVIII, используемого в качестве нелинейно-оптического хромофора и сенсибилизатора, и пластификатора-бензил-n-бутилфталата LXIX [180].

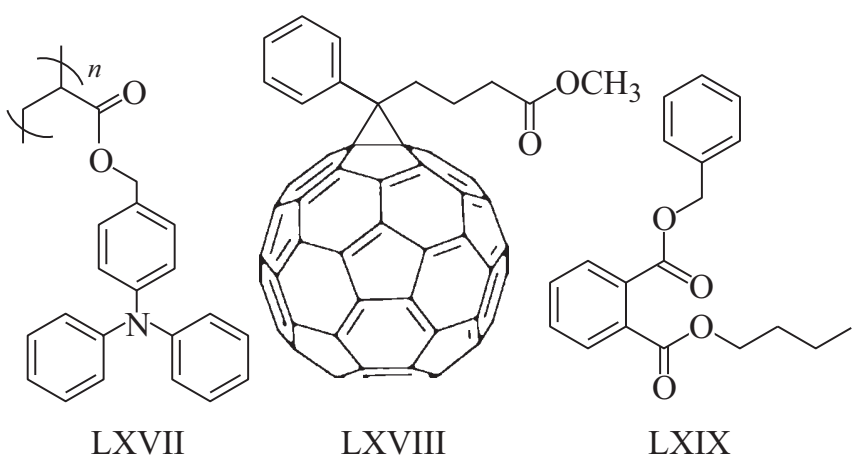

Такая среда обеспечивала регистрацию голограмм с высокой ДЭ лазерным излучением с длинами волн $\lambda=532,561,594 \mathrm{~nm}$ (рис. 15). При этом наименышее напряжение - 40 и даже $25 \mathrm{~V} / \mu \mathrm{m}$ - требовалось при записи голограмм излучением с длиной волны $\lambda=532 \mathrm{~nm}$.

Слои ПВС, содержащие бихромат калия и гексагидрат хлорида никеля, позволяют записывать голограммы излучением лазера с длиной волны $\lambda=442 \mathrm{~nm}$ в реальном времени и не требуют дополнительной химической или термической обработки для получения голограмм [181]. Приложение внешнего электрического поля $30 \mathrm{~V}$ увеличивает ДЭ голограмм до 4\%. Однако повышение влажности снижает значение этой величины.

Несмотря на достигнутые успехи в разработке фоторефрактивных органических материалов, необходимы дальнейшие усилия для повышения их светочувствительности, электрической и фотохимической стабильности. 


\section{4. Фоторефрактивные кристаллы}

К числу наиболее известных голографических регистрирующих сред этого типа относятся кристаллы ниобата лития $\left(\mathrm{LiNbO}_{3}\right)$, которые благодаря высоким фоторефрактивным свойствам рассматриваются как нелинейно-оптические материалы для реверсивной оптической памяти, фазового сопряжения, оптических вычислений и обработки оптической информации [182]. Однако они имеют ряд недостатков, которые ограничивают их применение, а именно медленную скорость фотоотклика, низкую светочувствительность, сильное фотоиндуцированное светорассеяние, энергозависимость.

Эти недостатки пытаются устранить введением в кристалл примесей различного типа. Исследование свойств кристаллов $\mathrm{Mg}: \mathrm{Ru}: \mathrm{Fe}: \mathrm{LiNbO}_{3}$ в зависимости от концентрации $\mathrm{Mg}$ при фиксированном содержании $\mathrm{Ru}$ и $\mathrm{Fe}$ показало, что увеличение мольной концентрации $\mathrm{Mg}$ до 0.7\% приводит к повышению времени отклика до $70 \mathrm{~s}$, регистрации голограмм с $\eta=59.8 \%$, при светочувствительности $42 \mathrm{~mJ} / \mathrm{cm}^{2}$, что существенно выше, чем для кристаллов $\mathrm{Ru}: \mathrm{Fe}: \mathrm{LiNbO}_{3}$ [183]. Кристаллы $\mathrm{Zn}$ (5.0 mol.\%): $\mathrm{Ru}: \mathrm{Fe}: \mathrm{LiNbO}_{3}$ по сравнению с кристаллами $\mathrm{Ru}: \mathrm{Fe}: \mathrm{LiNbO}_{3}$ характеризуются лучшими голографическими свойствами $[184,185]$. Голографические решетки записывались с $\eta=40 \%$ при светочувствительности $3 \mathrm{~mJ} / \mathrm{cm}^{2}$. Более приемлемыми свойствами обладают кристаллы $\mathrm{Zr}: \mathrm{Ru}: \mathrm{Fe}: \mathrm{LiNbO}_{3}$ : временем отклика $9.1 \mathrm{~s}$, ДЭ голограмм 44.9\% при светочувствительности $37 \mathrm{~mJ} / \mathrm{cm}^{2}$ [186]. Наиболее коротким временем фотоотклика обладают кристаллы $\mathrm{Mo}-\mathrm{LiNbO}_{3}$ $(0.35 \mathrm{~s})$, обеспечивающие регистрацию голограмм с $\eta=60 \%$ при их восстановлении излучением с длиной волны $351 \mathrm{~nm} \mathrm{[187].} \mathrm{Голограммы,} \mathrm{регистрируемые} \mathrm{в}$ кристаллах In : Ce: $\mathrm{Mn}: \mathrm{LiNbO}_{3}([\mathrm{Li}] /[\mathrm{Nb}]=1.38)$ излучением $\lambda=476 \mathrm{~nm}$ и восстанавливаемые излучением с $\lambda=633 \mathrm{~nm}$, возникают через $310 \mathrm{~s}$ [188]. Светочувствительность таких сред составляет $13 \mathrm{~mJ} / \mathrm{cm}^{2}$.

Кристаллы $\mathrm{Cu}: \mathrm{Fe}: \mathrm{LiNbO}_{3}$ использовались для получения двумерных голографических решеток излучением с $\lambda=532 \mathrm{~nm}$ [189]. Для предотвращения быстрого стирания решеток под действием того же излучения интенсивность считывающего пучка снижалась до уровня, обеспечивающего требуемое время жизни решетки. $\mathrm{Ha}$ примере кристалла $\mathrm{Fe}: \mathrm{LiNbO}_{3}$ теоретически рассмотрена динамика регистрации двумерных голографических решеток [190].

$\mathrm{B}$ кристаллах $\mathrm{Mn}: \mathrm{Fe}: \mathrm{LiNbO}_{3}$ регистрация голограмм осуществлялась излучением с $\lambda=633 \mathrm{~nm}$ с подсветкой сенсибилизирующим лазерным излучением с длиной волны $\lambda=405 \mathrm{~nm}$ [191]. При соотношении мольных концентраций $[\mathrm{Mn}] /[\mathrm{Fe}]=50 / 500$ голограммы записывались с $\eta=80 \%$ и с приемлемой светочувствительностью. Такую же светочувствительность при регистрации голограмм с $\eta=50 \%$ лазерным излучением с $\lambda=532 \mathrm{~nm}$ и УФ подсветке проявляют кристаллы $\mathrm{Mn}: \mathrm{Fe}: \mathrm{Hf}(5 \mathrm{~mol} . \%): \mathrm{LiNbO}_{3}$ при регистрации голограммы в течение $5 \mathrm{~s}$ [192].
Для применения в голографических исследованиях биообъектов в качестве регистрирующей среды предлагается использовать кристаллы $\mathrm{R}: \mathrm{Bi}_{12} \mathrm{SiO}_{20}$, которые обеспечивают запись голограмм ИК излучением с $\lambda=1064 \mathrm{~nm}$ [193]. Показано, что подсветка регистрируемых голограмм излучением с длиной волны $\lambda=532 \mathrm{~nm}$ в процессе их регистрации позволяет повысить скорость записи и увеличить время жизни голограмм. Кристаллы $\mathrm{Bi}_{2} \mathrm{TeO}_{5}$ использовались для записи динамических голограмм с $\eta=35 \%$ излучением гелий-неонового лазера $(\lambda=633 \mathrm{~nm})[194]$.

В отличие от рассмотренных выше фоторефрактивных кристаллов в полупроводниковых кристаллах $\mathrm{Cr}$ : GaAs голограммы с $\eta=90 \%$ регистрировались при наложении электрического $(500 \mathrm{~V} / \mathrm{m})$ и магнитного (640 Gs) полей [195]. Голограммы записывались импульсным лазерным ИК излучением $(\lambda=1064 \mathrm{~nm})$ при $77 \mathrm{~K}$. Времена записи и стирания голограмм составляли 2.5 и $2.0 \mathrm{~ns}$, соответственно. Это позволяло мультиплексировать голограммы.

\section{5. Фотохромные кристаллы}

В дополнение к известным фотохромным допированным щелочно-галоидным неорганическим кристаллам [112] и аддитивно окрашенным кристаллам фторида кальция (флюорита, $\left.\mathrm{CaF}_{2}\right)$ [196] для регистрации голограмм предлагается использовать допированные кристаллы $\mathrm{Ga}: \mathrm{CaF}_{2}$ и $\mathrm{In}: \mathrm{CaF}_{2}$, которые, как оказалось, также обладают фотохромными свойствами (рис. 16) [197]. Регистрация голограмм осуществлялась импульсным излучением второй гармоники неодимового лазера $(\lambda=532 \mathrm{~nm})$, а зондирование - излучением гелий-неонового лазера $(\lambda=633 \mathrm{~nm})$. Величина ДЭ голограмм зависела от температуры и изменялась от 80 до $0.1 \%$ при возрастании температуры от $77 \mathrm{~K}$ до комнатной. Время записи составляет десятки наносекунд при экспозиции около $0.5 \mathrm{~J} / \mathrm{cm}^{2}$. Время жизни голограммы зависело от температуры и изменялось от нескольких дней при $77 \mathrm{~K}$ до милли- и наносекунд при обычной температуре, в отличие от голограмм, записанных в кристаллах $\mathrm{CaF}_{2}$, время жизни которых

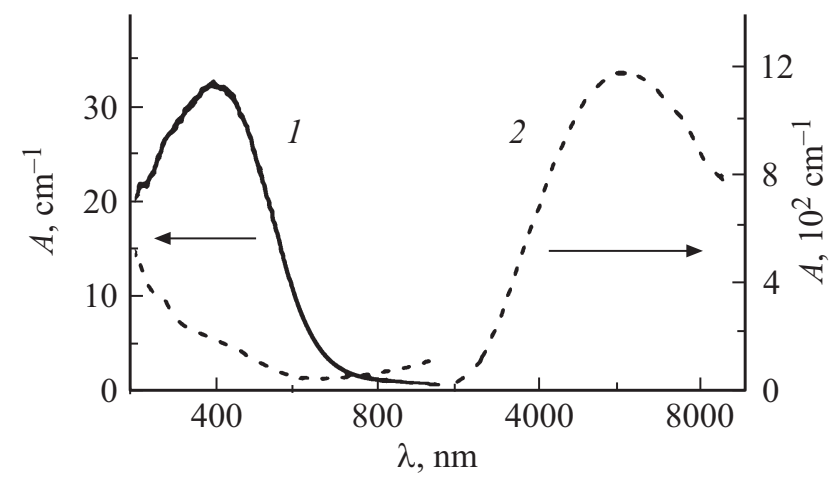

Рис. 16. Спектры поглощения полупроводникового кристалла $\mathrm{CdF}_{2}: \mathrm{In}$ при $77 \mathrm{~K}$ до (1) и после (2) УФ облучения [197]. 
при комнатной температуре практически неограниченно [196]. Разрешающая способность составляла не менее $5000 \mathrm{~mm}^{-1}$.

Выявлены особенности и различия регистрации голограмм в кристаллах $\mathrm{Ga}: \mathrm{CaF}_{2}$ и $\mathrm{CaF}_{2}$, исходя из механизмов фотохромных превращений этих кристаллов $[198,199]$.

\section{6. Фототермопластики}

Фотермопластические регистрирующие среды давно считаются одними из значимых реверсивных светочувствительных материалов для голографии, обеспечивающие обратимое получение рельефно-фазовых голограмм в несколько стадий: (а) зарядка поверхности среды коронным разрядом; (б) экспонирование светом; (в) проявление скрытого изображения; (г) стирание голограммы.

Основное внимание в разработке фототермопластических сред уделялось совершенствованию свойств полимерного фототермопластического слоя. Обнаружено, что голографическая светочувствительность и фотопроводимость слоев на основе глицидилкарбазольных сополимеров LXX и фотосенсибилизатора LXXI возрастают с увеличением концентрации ферроценовых соединений [200]. Этот эффект связывается с влиянием ионов железа на синглет-триплетный перенос энергии возбуждения. Однако такие слои не могут использоваться в качестве фототермопластических регистрирующих сред в силу их низких термопластических свойств.

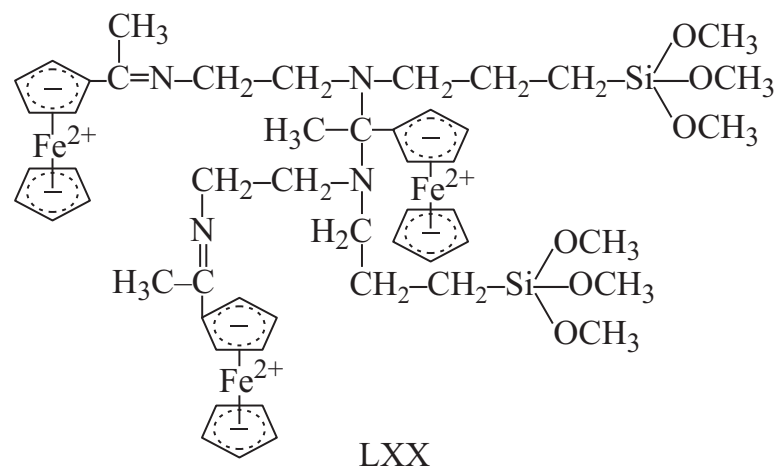<smiles>O=[N+]([O-])c1cc2c(c([N+](=O)[O-])c1)-c1c(cc([N+](=O)[O-])cc1[N+](=O)[O-])C2=Cc1ccc[Z7](F)c1</smiles>

LXXI

Фототермопластические слои на основе карбазол(LXXII) и ферроценил-(LXXIII) содержащих олигомеров совместно со скварилиевыми LXXIV или мероцианиновыми LXXV красителями, используемыми в качестве сенсибилизаторов, могут успешно применяться

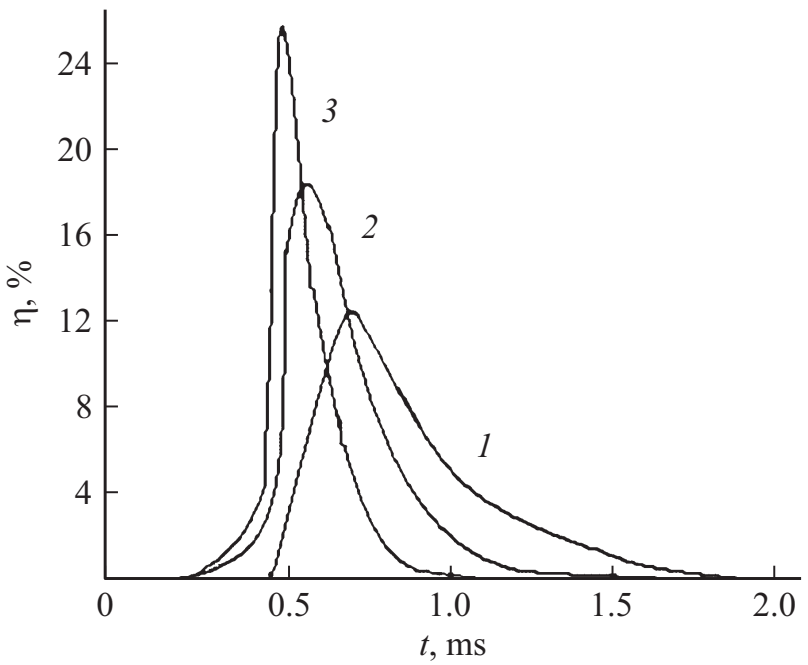

Рис. 17. Кинетические кривые фотоиндуцированного возрастания и термической релаксации величины ДЭ плоских голограмм в регистрирующих средах на основе сополимеров LXXX (1), LXXXI (2) и LXXXII (3) [202].

в голографических интерферометрических устройствах для определения остаточных напряжений, недеструктивного испытания частей машин и самих машин, изучения явлений транспорта частиц в жидкостях и для других применений [201].<smiles>CCOCC(C=O)Cn1c2ccccc2c2ccccc21</smiles>

LXXII

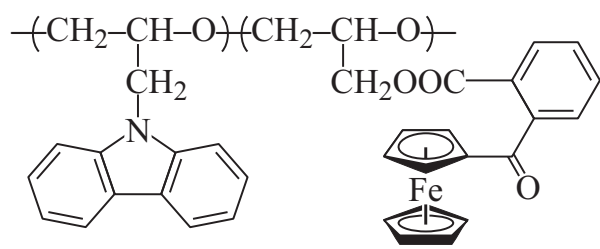

LXXIII<smiles>COC1=C(/C=C2/N(C)c3ccccc3C2(C)C)C(=O)/C1=C/C1[N+](C)c2ccccc2C1(C)C</smiles>

LXXIV<smiles>CN1/C(=C\C=C\C=C(C#N)C#N)C(C)(C)c2ccccc21</smiles>

Оптика и спектроскопия, 2018, том 124, вып. 3 
Исследование голографических свойств новых композитных фототермопластических материалов на основе сополимеров LXXVI-LXXVIII, содержащих нафтильные и другие фрагменты, и фотосенсибилизатора LXXIX показало, что величина ДЭ плоских голограмм, достигающая $10 \%$, зависит от температуры стеклования регистрирующего полимерного слоя и донорных свойств фрагментов [202]. Увеличение содержания атомов $\mathrm{Cl}$ в полимерных фрагментах снижает величину ДЭ.

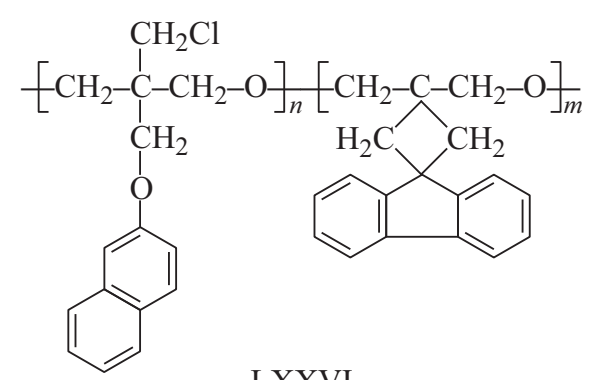

LXXVI<smiles>OCC(CCl)(CCl)COc1ccc2ccccc2c1</smiles>

LXXVII<smiles>OCC(CCl)(CCl)COc1ccc2ccccc2c1</smiles>

LXXVIII

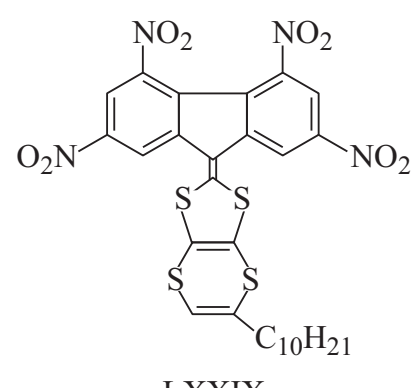

\section{LXXIX}

В результате сравнительного исследования фототермопластических слоев олигомеров линейной и радиальной структуры (LXXX-LXXXII), содержащих в качестве фотосенсибилизатора 2,7-динитро-9-дицианометиленфлуорен-4-карбоксильную кислоту LXXXIII, установлено, что олигомеры радиальной (звездно-подобной) структуры обеспечивают наибольшую голографическую светочувствительность (рис. 17) [203,204].<smiles>CCOCC(CC(C)(C)C)OC(CC)Cn1c2ccccc2c2ccccc21</smiles>

LXXX<smiles>CCOCC(C)Cn1c2ccccc2c2ccccc21</smiles>

LXXXI<smiles>C[Si](C)(O)OC(COCC1CCCCC1)Cn1c2ccccc2c2ccccc21</smiles>

LXXXII<smiles>CCCCCOC(=O)c1cc([N+](=O)[O-])cc2c1-c1ccc([N+](=O)[O-])cc1C2=C(C#N)C#N</smiles>

Это объясняется увеличением пластичности слоя и способностью пространственной аккумуляции заряда в процессе облучения слоя.

Подобные результаты получены для слоев сополимеров того же типа (LXXXIV-LXXXVI) с другим фотосенсибилизатором (LXXXVII) [205].<smiles>C[Si](O)(OCC(O)Cn1c2ccccc2c2ccccc21)c1ccccc1</smiles>

LXXXIV

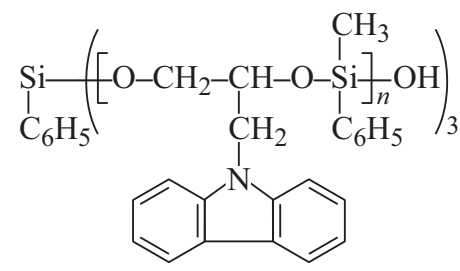

LXXXV

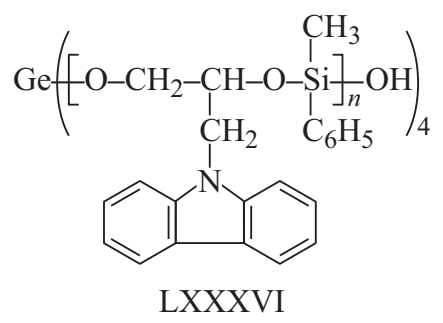


<smiles>CCCCCOc1cccc(C2=C[Se]C(=C3c4cc([N+](=O)[O-])cc([N+](=O)[O-])c4-c4c3cc([N+](=O)[O-])cc4[N+](=O)[O-])S2)c1</smiles>

LXXXVII

В результате исследования фототермопластических слоев на основе сополимеров глицидил-карбазола и нафтил-глицидил эфира (LXXXVIII-XC), а также сополимеров 1,3,6-трибромглицидил карбазола и нафтилглицидил эфира (XCI-XCIII) с использованием в качестве сенсибилизатора соединение с внутримолекулярным переносом заряда XCIV установлено, что при увеличении количества глицидил-карбазольных фрагментов в сополимерах первого типа фотопроводимость растет, а величина ДЭ голограмм снижается [206]. Более эффективными оказались слои на основе сополимеров с бром-содержащими фрагментами.

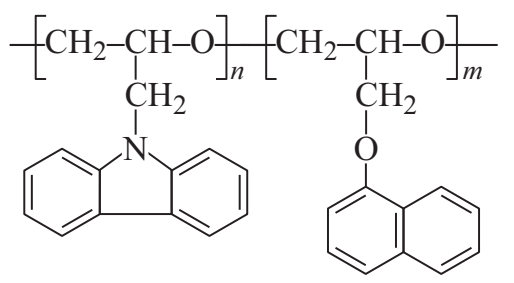

$(n: m=1: 2) ;(n: m=1: 1) ;(n: m=2: 1)$

LXXXVIII-XC

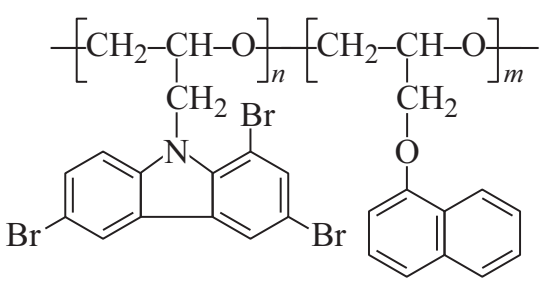

$(n: m=1: 2) ;(n: m=1: 1) ;(n: m=2: 1)$

XCI-XCIII<smiles>CCCCOC(=O)c1cc([N+](=O)[O-])cc2c1-c1c(cc([N+](=O)[O-])cc1[N+](=O)[O-])C2=C1SC(c2ccc(OCCCC)cc2)=C[Se]1</smiles>

LCIV

\section{7. Регистрирующие среды нового типа}

Рассмотренные выше фоторефрактивные среды органического и неорганического типа обладают одним существенным недостатком, а именно динамическим характером голограмм, не позволяющим реализовать оперативную голографическую трехмерную память. Этим недостатком не обладают фотохромные полимерные материалы на основе термически необратимых диарилэтенов. Однако фотохромные материалы обеспечивают регистрацию амплитудно-фазовых голограмм с ограниченной величиной ДЭ. В связи с этим представляет интерес новая светочувствительная полимерная среда на основе наночастиц различного типа, в частности Ag-наночастиц [207].

Полимерный слой получали методом радикальной полимеризации композиции, состоящей из гидроксиэтил метакрилата, сшивающего реагента - этилендиметилакрилата и метакриловой кислоты. Сначала полимерный слой пропитывался раствором $\mathrm{AgNO}_{3}$ и насыщался ионами $\mathrm{Ag}^{+}$. Затем в результате обработки бромистым литием образовывались светочувствительные нанокристаллы $\mathrm{AgBr}$, которые облучались. В результате фотографического проявления засвеченных кристаллов возникали наночастицы металлического серебра $\mathrm{Ag}^{\circ}$. Действие проявителя прекращалось снижением $\mathrm{pH}$ до 3.0. Оставшиеся нанокристаллы удалялись обработкой слоя тиосульфатом. В результате получалась регистрирующая среда с высоким разрешением.

Обратимость регистрации голограмм в таких средах обусловлена обратимым образованием $3 D$-ансамблей наночастиц под действием оптических сил, определяемых интерференционной картиной, возникающей при регистрации голограмм под различными углами. Стирание голограмм достигалось облучением регистрирующей среды перпендикулярно ее размещению. Разница в показателях преломления среды в необлученных и облученных участках среды составляла $\Delta n=1.43-1.37=0.06$, что обеспечивало запись голограмм с высокой ДЭ. Запись голограмм осуществлялась по схеме Денисюка импульсным излучением неодимового лазера $(5 \mathrm{~ns}, 532 \mathrm{~nm}$, $350 \mathrm{~mJ}$ ). Число циклов записи и стирания голограмм в такой среде достигало 40. Среда обладала высокой угловой селективностью и обеспечивала высокое качество восстановленного $3 D$-изображения.

Для необратимой записи голограмм предложен ряд нетоксичных светочувствительных регистрирующих сред на основе новых компонентов, в частности слои на основе альбумина с использованием добавок сахара и бихромата аммония [208]. Голограммы с $\eta=25.56 \%$ регистрировались при экспозиции около $1.5 \mathrm{~J} / \mathrm{cm}^{2}$ [209]. Использовались также слои гуммиарабика, характеризующиеся высокими оптическими свойствами, влагостойкостью и приемлемой адгезией к подложке, а также нетоксичностью и простотой изготовления [210]. Голограммы с $\eta=6-8 \%$ при экспозициях $0.6 \mathrm{~J} / \mathrm{cm}^{2}$ зарегистрированы излучением лазерного диода $(\lambda=473 \mathrm{~nm})$ в слоях бихромата глюкозы и фруктозы [211]. 


\section{Заключение}

Анализ свойств разрабатываемых голографических сред различного типа показывает, что в целом созданный ранее ассортимент светочувствительных материалов обеспечивает успешное развитие голографии.

Среди необратимых светочувствительных регистрирующих сред созданные мелкозернистые галогенидсеребряные материалы успешно применяются в изобразительной, в том числе цветной голографии, чему способствует их высокая светочувствительность. Для получения высококачественных ГОЭ, особенно больших размеров, пригодны светочувствительные слои бихромированной желатины. Несомненно, выдающиеся результаты достигнуты в разработке фотополимеризующихся материалов. Они обладают приемлемой светочувствительностью, регистрацией голограмм с высокой ДЭ в реальном времени без существенной дополнительной обработки. Благодаря достижениям последних лет разработаны регистрирующие среды для цветной изобразительной голографии, изготовления ГОЭ и $3 D$ оптической памяти архивного типа [193]. Благодаря использованию наночастиц различных неорганических веществ успешно решены проблемы создания практически безусадочных голографических регистрирующих сред. В этом отношении к ним приближаются по свойствам полимерные среды с фотохимической пришивкой светочувствительных молекул к полимерной матрице. Разработан ряд органических и неорганических, в частности халькогенидных сред для получения рельефнофазовых голограмм, применяемых в производстве защитных голограмм.

Значительно меньшие успехи достигнуты в разработке реверсивных светочувствительных регистрирующих сред. Среди созданных сред наиболее приемлемыми представляются фотохромные органические материалы, особенно на основе термически необратимых фотохромных соединений из класса диарилэтенов. Основным препятствием их широкого применения является низкие светочувствительность и ДЭ в силу амплитуднофазового характера регистрируемых голограмм. Особенно широкие исследования в области разработки фотохромных регистрирующих сред ведутся с использованием азобензол-содержащих полимерных систем, в том числе на основе ЖК. Они позволяют записывать реверсивные рельефные и поляризационные голограммы, обеспечивая тем самым расширение областей применения голографии. Разработанные фотополимеризующиеся композиции, содержащие ЖК, позволили создать электроуправляемые голографические светофильтры. Потребности динамической голографии удовлетворяются созданными электрооптическими материалами с использованием как органических полимеров, так и допированных ионами металлов кристаллов типа $\mathrm{LiNBO}_{3}$, $\mathrm{Bi}_{2} \mathrm{TeO}_{5}$, а также полупроводниковых кристаллов типа $\mathrm{CaF}_{2}$, проявляющих нелинейно-оптические свойства. Традиционные реверсивные фототермопластические голографические материалы продолжают совершенство- ваться в направлении повышения светочувствительности и разрешающей способности.

Представляется, что в дальнейшем основные усилия в разработке голографических регистрирующих сред будут направлены на совершенствование светочувствительных материалов для $3 D$-архивной и оперативной оптической памяти [193].

\section{Список литературы}

[1] Barachevsky V.A. // Proc. SPIE. 2000. V. 4149. P. 205.

[2] Барачевский В.A. // Всероссийский семинар „Юрий Николаевич Денисюк - основоположник отечественной голографии“. Сб. тр. СПб.: ФТИ им. А.Ф. Иоффе РАН, СПбГУ ИТМО, НПК ГОИ им. С.И. Вавилова. 2007. C. $226-240$.

[3] Fimia A., Acebal P., Blaya S., Carretero L., Murciano A., Madrigal R.F. // Proc. SPIE. 2009. V. 7358. P. 735802-1.

[4] „Company SLAVICH“, http://www.slavich.ru (accessed September 10, 2015).

[5] Vorzobova N.D., Sokolova Y.V., Kalinina N.M., Ryabova R.V., Ponomarev A.N. // Mol. Cryst. Liq. Cryst. 2011. V. 535. P. 167.

[6] Рябова Р.В., Пономарев А.Н., Ворзобова Н.Д. // Опт. и спектр. 2014. Т. 117. № 2. С. 142; Ryabova R.V., Ponomarev A.N., Vorzobova N.D. // Opt. Spectr. 2014. V. 117. P. 137.

[7] Ганжерли Н.М., Гуляев С.Н., Маурер И.А., ЧерHblx Д.Ф. // ЖТФ. 2014. Т. 84. С. 112; Ganzherli N.M., Gulyaev S.N., Maurer I.A., Chernykh D.F. // Technical Physics. 2014. V. 59. P. 1849.

[8] Smith S.L., Harvey K., Richardson M., Blyth J. // Proc. SPIE. 2011. V. 7957. P. 79570J-1.

[9] Stojanoff C.G. // Proc. SPIE. 2011. V. 7957. P. 79570L-1.

[10] Dai R., Chen S., Ren Z., Wang Z., Liu D. // Appl. Phys. B. 2012. V. 109. P.15.

[11] Ramirez M.G., Quintana J.A., Villalvilla J.M., Boj P.G., Retolaza A., Merino S., Diaz-Garcıa M.A. // J. Appl. Phys. 2013. V. 114. P. 033107-1.

[12] Orozco-Muñoz R.E., Ortiz-Gutiérrez M., Salgado-Verduzco M.A., Ibarra-Torres J.C., Olivares-Pérez A., ToxquiLópez S., Pérez-Cortés M. // Proc. SPIE. 2014. V. 9006. P. $90061 \mathrm{~K}-1$.

[13] Gleeson M.R., Guo J., Sheridan J.T. // New Polymers for Special Applications / Ed. by Gomes A.D.S. 2012. P. 165200.

[14] Guo J., Gleeson M.R., Sheridan J.T. // Phys. Res. Intern. 2012. V. 2012. P. ID 803439-1.

[15] Gallego S., M'arquez A., Ortuño M., Neipp C., Pascual I., Beléndez A. // Phys. Res. Intern. 2012. Art. ID 352681. P. 1.

[16] Sheridan J.T., Gleeson M., Close C. // J. Opt. Soc. Am. B. 2012. V. 29. P. 460.

[17] Gallego S., Neipp C., Estepa L.A., Ortuño M., Márquez A., Francés J., Pascual I., Beléndez A. // Mater. 2012. V. 5. P. 1373.

[18] Song W., Tao S., Wang D., Wang Y., Marx L. // Adv. Mater. Res. 2013. V. 652-654. P. 638.

[19] Song W., Tao S., Zhai Q., Wang D. // Opt. Eng. 2013. V. 52. P. 045801-1. 
[20] Lucchetta D.E., Nucara L., Criante L., Simoni F., Boni A., Xu J.-H., Bizzarri R., Castagna R. // J. Appl. Phys. 2013. V. 114. P. 193101-1.

[21] Qi Y., Gleeson M.R., Guo J., Gallego S., Sheridan J.T. // Phys. Res. Intern. 2012. V. 2012. Art. ID 975948. P. 1.

[22] Qi Y., Li H., Fouassier J.P., Lalevée J., Sheridan J.T. // Appl. Optics. 2014. V. 53. P. 1052.

[23] Ibrahim A., Ley C., Allonas X., Tarzi O.I., Yong A.C., Carré C., Chevallier R. // Photochem. Photobiol. Sci. 2012. V. 11. P. 1682

[24] Ibrahim A., Allonas X., Ley C., El Fouhaili B., Carré C. // J. Photopol. Sci. Technol. 2014. V. 27. P. 517.

[25] Ibrahim A., Ley C., Allonas X., Carré C., Pillin I. // J. Displ. Technol. 2014. V. 10. P. 456.

[26] Nimmi K.P., Pramitha V., Sreekumar K., Kartha C.S., Joseph R. // J. Appl. Polym. Sci. 2012. V. 125. P. 1238.

[27] Sabel T., Orlic S., Pfeiffer K., Ostrzinski U., Grützner G. // Opt. Mater. Express. 2013. V. 3. P. 329.

[28] Кио C.-Y., Hsu T.-C., Su W.-H. // J. Non-Cryst. Solids. 2012. V. 358. P. 735.

[29] Jeong Y.-C., Heo Y., Lee J., Lee S., Ahn D., Park J.-K. // Opt. Mater. 2013. V. 35. P. 547.

[30] Blaya S., Acebal P., Carretero L., Madrigal R.F., Murciano A., Fimia A. // Proc. SPIE. 2011. V. 8074. P. $80740 \mathrm{~V}-1$.

[31] Srivastava A., Sawant S.M., Mainali L., Bhatt R., Gupta A.K., Samui A.B. // Polym. Adv. Technol. 2012. V. 23. P. 967.

[32] Lin H., de Oliveira P.W., Veith M. // Opt. Mater. 2011. V. 33. P. 759.

[33] Mikulchyk T., Martin S., Naydenova I. // J. Opt. 2013. V. 15. P. 105301.

[34] Cody D., Naydenova I., Mihaylova E. // J. Opt. 2012. V. 14. P. 015601.

[35] Cody D., Casey A., Naydenova I., Mihaylova E. // Int. J. Polym. Sci. 2013. Art. ID 564319. P. 1.

[36] Cody D., Naydenova I., Mihaylova E. // Proc. SPIE. 2012. V. 8429. P. 84291B-1.

[37] Cody D., Naydenova I., O'Neill L., Mihaylova E. // Opt. Mater. 2015. V. 48. P. 12.

[38] Cody D., Naydenova I., Mihaylova E. // Appl. Opt. 2013. V. 52. P. 489.

[39] Cody D., Gribbin S., Naydenova I., Mihaylova E. // ACS Appl. Mater. Interfaces. 2016. V. 8. P. 18481.

[40] Ortuño M., Gallego S., Márquez A., Neipp C., Pascual I., Beléndez A. // Materials. 2012. V. 5. P. 772.

[41] Toxqui-López S., Olivares-Pérez A., Pinto-Iguanero B., Aguilar-Mora A., Fuentes-Tapia I. // Proc. SPIE. 2012. V. 8281. P. 828102-1.

[42] Toxqui-López S., Olivares-Pérez A., Fuentes-Tapia I. // Proc. SPIE. 2013. V. 8644. P. 864416-1.

[43] Steinberg I.S., Vasilyev E.V., Belikov A.Y. // J. Opt. 2013. V. 15. P. 105403-1.

[44] Rajesh C.S., Anjana R., Sreeroop S.S., Kartha C.S. // Pramana - J. Phys. 2014. V. 82. P. 259.

[45] Zhao Y., Zhong J., Ye Y., Luo Z., Li J., Li Z., Zhu J. // Mater. Lett. 2015. V. 138. P. 284.

[46] Fernandez E., Fuentes R., Márquez A., Beléndez A., Pascual I. // Intern. J. Polym. Sci. 2014. Art. ID 356534. P. 1.
[47] Gleeson M.R., Sheridan J.T., Bruder F.-K., Rölle T., Berneth H., Weiser M.-S., Fäcke T. // Opt. Express. 2011. V. 19. P. 26325.

[48] Jurbergs D., Bruder F.-K., Deuber F., Fäcke T., Hagen R., Hönel D., Rölle T., Weiser A., Volkov M.-S. // Proc. SPIE. V. 7233. P. 72330K-1.

[49] Gleeson M.R., Guo J., Sheridan J.T. // New Polymers and Special Applications. InTech. 2012. P. 165.

[50] Guo J., Gleeson M.R., Sheridan J.T. // Proc. SPIE. 2013. V. 8776. P. $87760 \mathrm{~J}-1$.

[51] Askham F. U.S. Patent 8,323,854, 2012.

[52] Anderson K., Ayres M., Sissom B., Askham F. // Proc. SPIE. 2014. V. 9006 . P. $90060 \mathrm{C}-1$.

[53] Ayres M.R., Anderson K., Askham F., Sissom B., Urness A.C. // Proc. SPIE. 2015. V. 9587. P. 958702-1.

[54] Ayres M.R., Anderson K., Askham F., Sissom B. // Proc. SPIE. 2014. V. 9201. P. $92010 \mathrm{~V}-1$.

[55] Ayres M.R., Anderson K., Askham F., Sissom B., Urness A.C. // Proc. SPIE. 2015. V. 9386. P. 93860G-1.

[56] Askham F., Ayres M.R., Urness A.C. // Proc. SPIE. 2015. V. 9587. P. 958708-1.

[57] Bruder F.-K., Hagen R., Rolle T., Weiser M.-S., Facke T. // Angew. Chem. Int. Ed. 2011. V. 50. P. 4552.

[58] Nazarov M.M., Khaydukov K.V., Sokolov V.I., Khaydukov E.V. // Quant. Electron. 2016. V. 46. P. 29.

[59] Tomita Y., Hata E., Momose K., Takayama S., Liu X., Chikama K., Klepp J., Pruner C., Fally M. // J. Modern Opt. 2016. V. 63. P. S11.

[60] Denisyuk I.Yu., Burunkova Ju.A., Kokenyesi S., Bulgakova V.G., Fokina M.I. // Nanocrystals-Synthesis, Characterization and Applications / Ed. by Neralla S. InTech. 2012. P. 8-1-102.

[61] Смирнова Т.Н., Кохтич Л.М., Сахно О.В., Штумпе И. // Опт. и спектр. 2011. Т. 110. Р. 135; Smirnova T.N., Kokhtich L.M., Sakhno O.V., Stumpe J. // Opt. Spectr. 2011. V. 110. P. 129.

[62] Смирнова Т.Н., Кохтич Л.М., Сахно О.В., Штумпе И. // Опт. и спектр. 2011. Т. 110. С. 143; Smirnova T.N., Kokhtich L.M., Sakhno O.V., Stumpe J. // Opt. Spectr. 2011. V. 110. P. 137.

[63] Han S., Lee M., Kim B.K. // Opt. Mater. 2011. V. 34. P. 131.

[64] Kawana M., Takahashi J.-i., Yasui S., Tomita Y. // J. Appl. Phys. 2015. V. 117. P. 053105-1.

[65] Mitsube K., Nishimura Y., Takayama S., Nagaya K., Tomita Y. // Proc. SPIE. 2013. V. 8776. P. 87760I-1.

[66] Moothanchery M., Bavigadda V., Toal V., Naydenova I. // Appl. Opt. 2013. V. 52. P. 8519.

[67] Huang M., Li R. // Proc. SPIE. 2013. V. 8782. P. 878204-1.

[68] Sun X., Wang J. // Proc. SPIE . 2013. V. 8782. P. 878202-1.

[69] Velasco A.V., Calvo M.L., Cheben P. // J. Appl. Phys. 2013. V. 113. P. 033101-1.

[70] Ni M., Peng H., Liao Y., Yang Z., Xue Z., Xie X. // Macromolecules. 2015. V. 48. P. 2958.

[71] Kveton M., Havranek A., Fiala P., Skeren M., Simov I. // Proc. SPIE. V. 8697. P. 869709-1.

[72] Pramitha V., Nimmi K.P., Subramanyan N.V., Joseph R., Sreekumar K., Kartha C.S. // Appl. Opt. 2009. V. 48. P. 2255.

[73] Pramitha V., Das B., Joseph J., Joseph R., Sreekumar K., Kartha C.S. // Opt. Mater. 2016. V. 52. P. 212.

[74] Xue X.-Y., Hai F.-S., Gao L.-Z., He F., Li C.-L., Li Y.-X. // Proc. SPIE. 2013. V. 8782. P. 87820D. 
[75] Tomita Y., Hata E., Yasui S., Mitsube K. // Proc. SPIE. 2011. V. 8074. P. 80740 F-1.

[76] Hata E., Mitsube K., Momose K., Tomita Y. // Opt. Mater. Express. 2011. V. 1. P. 207.

[77] Barichard A., Galstian T., Israeli Y. // Phys. Chem. Chem. Phys. 2012. V. 14. P. 8208.

[78] Jeong Y.-C., Jung B., Park J.-K. // Macromol. Res. 2012. V. 20. P. 623.

[79] Jeong Y.-C., Jung B., Park J.-K. // ACS Appl. Mater. Interfaces. 2012. V. 4. P. 4921.

[80] Klepp J., Pruner C., Tomita Y., Plonka-Spehr C., Geltenbort P., Ivanov S., Manzin G., Andersen K.H., Kohlbrecher J., Ellabban M.A., Fally M. // Phys. Rev. A. 2011. V. 84. P. 013621-1.

[81] Zhuk D.I., Burunkova J.A., Denisyuk I.Yu., Miroshnichenko G.P., Csarnovics I., Toth D., Bonyar A., Veres M., Kokenyesi S. // Polym. 2017. V. 112. P. 136.

[82] Tomita Y., Momose K., Hata E., Takayama S. // Proc. SPIE. 2012. V. 8429. P. 842918-1.

[83] Ворзобова Н.Д., Булгакова В.Г., Веселов В.О. // Опт. и спектр. 2015. T. 119. С. 1033; Vorzobova N.D., Bulgakova V.G., Veselov V.O. // Opt. Spectr. 2015. V. 119. P. 1034.

[84] Tomita Y., Hata E., Momose K., Takayama S., Liu X., Chikama K., Klepp J., Pruner C., Fally M. // J. Modern Opt. 2016. V. 63. P. S11.

[85] Вениаминов А.В., Могильный В.В. // Опт. и спектр. 2013. T. 115. C. 1014; Veniaminov A.V., Mahilny U.V. // Opt. Spectr. 2013. V. 115. P. 906.

[86] Liu H., Yu D., Wang J., Jiang Y., Sun X. // Optics \& Laser Technol. 2012. V. 44. P. 882.

[87] Hsieh M.-L., Chen W.-C., Chen H.-Y., Lin S.-Y. // Opt. Comm. 2013. V. 308. P. 121.

[88] Chen Y.-F., Lin J.-H., Lin S.H., Hsu K.Y., Whang W.-T. // Opt. Lett. 2013. V. 38. P. 2056.

[89] Liu H., Yu D., Yang L., Wang W., Zhang L., Wang H., Sun X. // Opt. Comm. 2012. V. 285. P. 4993.

[90] Ko C.-J., Chen P.-L., Hsiao Y.-N., Lin S.-H., Whang W.-T., Hsu K.Y., Huang K.-J., Chen C.-C., Tseng I.-H., Tsai M.-H. // Polym. Eng. Sci. 2013. P. 1297.

[91] Ko C.-J., Hsiao Y.-N., Lin S.-H., Chen P.-L., Whang W.-T., Hsu K.Y., Hsiao Y.-S., Chen C.-C. // J. Appl. Polym. Sci. 2013, APP. 37835. P. 643.

[92] Lin S.H., Cho S.-L., Chou S.-F., Lin J.H., Lin C.M., Chi S., Hsu K.Y. // Opt. Express. 2014. V. 22. P. 14944.

[93] Liu Y., Li Z., Zang J., Wu A., Wang J., Lin X., Tan X., Barada D., Shimura T., Kuroda K. // Opt. Rev. 2015. V. 22. P. 837.

[94] Мармыш Д.Н., Могильный В.В. // ЖТФ. 2013. Т. 83. C. 120; Marmysh D.N., Mahilny U.V. // Techn. Phys. 2013. V. 58. P. 1666.

[95] Matusevich V., Tolstik E., Kowarschik R., Egorova E., Matusevich Y.I., Krul L. // Opt. Comm. 2013. V. 295. P. 79.

[96] Tolstik E., Egorova E., Hoff D., Matusevich V., Yakimtsova L.B., Matusevich Y.I., Kowarschik R., Krul L.P. // J. Polym. Res. 2012. V. 19. P. 9742-1.

[97] Матусевич Ю.И., Круль Л.П. // Журн. прикл. химии. 2013. T. 86. C. 1288; Matusevich Yu.I., Krul L.P. // Rus. J. Appl. Chem. 2013. V. 86. P. 1262.

[98] Zhizhchenko A.Yu., Vitrik O.B., Kulchin Yu.N. // Opt. Mater. 2016. V. 46. P. 265.

[99] Al-Saymari F.A., Badran H.A., Al-Ahmad A.Y., Emshary C.A. // Indian J. Phys. 2013. V. 87. P. 1153.
[100] Vallejo-Mendoza R., Olivares-Pérez A., Korneev $N$., Dorantes-García V., Ordóñez-Padilla M.J. // Proc. SPIE. 2012. V. 8281. P. 828114-1.

[101] Toxqui-Lopez S., Hernández-Hernández E., SantacruzVázquez C., Olivares-Pérez A. // Proc. SPIE. 2014. V. 9006. P. $90061 \mathrm{~A}-1$.

[102] Olivares-Pérez A., Toxqui-López S., L. Padilla-Velasco A. // Materials. 2012. V. 5. P. 2383.

[103] Olivares-Perez A., Toxqui-López S., Fuentes-Tapia I., OrtizGutiérrez M., Mellano-Villasenor G. // Proc. SPIE. 2012. V. 8281. P. 828103-1.

[104] Zhu M., Zhong H., Jia J., Fu W., Liu J., Zou B., Wang Y. // Adv. Opt. Mater. 2014. V. 2. P. 338.

[105] Andries A., Abaskin V., Achimova E., Meshalkin A., Prisacar A., Sergheev S., Robu S., Vlad L. // Phys. Status Solidi A. 2011. V. 208. P. 1837.

[106] Ozols A., Augustovs P., Saharov D. // Lithuan. J. Phys. 2012. V. 52. P. 10.

[107] Teteris J., Reinfelde M., Aleksejeva J., Gertners U. // Phys. Procedia. 2013. V. 44. P.151.

[108] Krivoshlykov S.G. // Appl. Opt. 2015. V. 54. P. 3569.

[109] Stronski A., Achimova E., Paiuk O., Meshalkin A., Abashkin V., Lytvyn O., Sergeev S., Prisacar A., Triduh G. // Nanoscale Res. Lett. 2016. V. 11. P. 1.

[110] Stronski A., Achimova E., Paiuk O., Meshalkin A., Prisacar A., Triduh G., Oleksenko P., Lytvyn P. // Nanosc. Res. Lett. 2017. V. 12. P. 286-1.

[111] Mikaeliane A., Axenchikov A., Bobrinev V., Gulaniane E., Shatun V. // IEEE J. Quant. Electron. 1968. V. 4. P. 757.

[112] Барачевский В.А., Лашков Г.И., Цехомский В.А. Фотохромизм и его применение. М.: Химия, 1977. 277 с.

[113] Fu S., Sun S., Sang W., Sun B., Zhang X., Liu Y. // Proc. SPIE. 2012. V. 8559. P. 85590G-1.

[114] Fua S., Wang X., Hu W., Xie M., Zhang X., Liu Y. // Opt. 2013. V. 124. P. 139.

[115] Janfaza S., Rad A.M., Khayati M., Etemadzadeh A., Jamshidinia Z. // Turk. J. Biochem. 2013. V. 38. P. 468.

[116] Ishii N., Kato T., Abe J. // Sci. Rep. 2012. V. 2. P. 819-1.

[117] He S., Liu G., Cui S. // Adv. Mater. Res. 2013. V. 763. P. 61.

[118] He S., Liu G., Cui S. // Appl. Mechan. Mater. 2012. V. 164. P. 166.

[119] Sun F., Pu S., Cui S. // Appl. Mechan. Mater. 2013. V. 327. P. 73.

[120] Wang L., Pu S., Yan L., Cui S. // Adv. Mater. Res. 2011. V. 295-297. P. 1042.

[121] Wang L., Pu S., Yan L. // Appl. Mechan. Mater. 2012. V. 164. P. 235.

[122] Wang R., Ren P., Cui S., Pu S. // Adv. Mater. Res. 2013. V. 763. P. 88.

[123] Yan P., Tong Z., Pu S., Liu W. // Adv. Mater. Res. 2011. V. 156-157. P. 655.

[124] Kajimura M., Egami C. // Mol. Cryst. Liq. Cryst. 2016. V. 635. P. 102.

[125] Cao L., Wang Z., Zong S., Zhang S., Zhang F., Jin G. // J. Pol. Sci. B. 2016. V. 54. P. 2050.

[126] Zong Z., Menke N., Yao B., Wang Y., Chen Y. // Appl. Mechan. Mater. 2012. V. 130-134. P. 2035.

[127] Gallego-Gómez F., del Monte F., Meerholz K. // Adv. Funct. Mater. 2013. V. 23. P. 3770.

[128] Berges C., Oriol L., Piñol M., Sánchez-Somolinos C., Alcalá R. // Opt. Mater. 2013. V. 35. P. 1095. 
[129] Berges C., Javakhishvili I., Hvilsted S., SanchezSomolinos C., Alcala R. // Appl. Phys. Lett. 2013. V. 102. P. 193303-1.

[130] Berges C., Díez I., Javakhishvili I., Hvilsted S., SanchezSomolinos C., Alcalá R. // Opt. Mater. 2014. V. 36. P. 845.

[131] Chaganava I., Kakauridze G., Kilosanidze B. // Proc. SPIE. 2011. V. 7957. P. 795714-1.

[132] Zhao F., Wu J., Pan Z., Wang C., Zhang J., Zeng Y., Lu X. // Opt. Comm. 2012. V. 285. P. 4180.

[133] Davidenko I.I. // Opt. Mater. 2012. V. 34. P. 679.

[134] Ono H., Izawa M., Sasaki T., Noda K., Nishioka E., Kawatsuk N. // Jpn. J. Appl. Phys. 2013. V. 52. P. 011602-1.

[135] Probst C., Meichner C., Audorff H., Walker R., Kreger K., Kador L., Schmidt H.-W. // J. Polym. Sci., B: Polym. Phys. 2016. V. 54. P. 2110.

[136] Audorff H., Walker R., Kador L., Schmidt H.-W. // Chem. Eur. J. 2011. V. 17. P. 12722.

[137] Rahmouni A., Bougdid Y., Moujdi S., Nesterenko D.V., Sekkat Z. // J. Phys. Chem. B. 2016. V. 120. P. 11317.

[138] Shaverdova V., Petrova S., Purtseladze A., Tarasashvili L., Obolashvili N. // Proc. SPIE. 2011. V. 7957. P. 79570U-1.

[139] Aleksejeva J., Teteris J., Tokmakovs A. // Phys. Procedia. 2013. V. 44. P. 19.

[140] Kirby R., Sabat R.G., Nunzi J.-M., Lebel O. // J. Mater. Chem. C. 2014. V. 2. P. 841.

[141] Gerbreders A., Bulanovs A., Mikelsone J., Traskovskis K., Potanina E., Vembris A., Teteris J. // J. Non-Cryst. Solids. 2015. V. 421. P. 48.

[142] Nedelchev L., Nazarova D., Dragostinova V., Karashanova D. // Opt. Lett. 2012. V. 37. P. 2676.

[143] Nazarova L., Nedelchev D., Sharlandjiev P., Dragostinova V. // Appl. Opt. 2013. V. 52. P. E28.

[144] Berberova N., Nazarova L., Nedelchev B., Blagoeva D., Kostadinova V., Marinova E., Stoykova E. // J. Phys. Conf. Ser. 2016. V. 700. P. 012032-1.

[145] Berberova N., Daskalova D., Strijkova V., Kostadinova D., Nazarova D., Nedelchev L., Stoykova E., Marinova V., Chi C.H., Lin S.H. // Opt. Mater. 2017. V. 64. P. 212.

[146] Aleksejeva J., Reinfelde M., Teteris J. // Can. J. Phys. 2014. V. 92. P. 1.

[147] Goldenberg L.M., Kulikovsky L., Gritsai Y., Kulikovska O., Tomczyk J., Stumpe J. // J. Mater. Chem. 2010. V. 20. P. 9161.

[148] Aleksejeva J., Teteris J. // J. Non-Cryst. Solids. 2013. V. 377. P. 209.

[149] Häckel M., Kador L., Kropp D., Schmidt H.-W. // Adv. Mater. 2007. V. 19. P. 227.

[150] Mazaheri L., Ahmadi-Kandjani S., Nunzi J.-M. // Jpt. Commun. 2013. V. 298-299. P. 150.

[151] Sobolewska A., Zawada J., Bartkiewicz S. // Langmuir. 2014. V. 30. P. 17.

[152] Zhang Y., Zhang J., Cui Z., Chen Q., Zhang H., Jiang Z. // J. Polym. Sci. A. 2015. V. 53. P. 936.

[153] Liu Y.J., Dai H.T., Sun X.W. // J. Mater. Chem. 2011. V. 21. P. 2982.

[154] Freschi A.A., de Vicente F.S. Mello T.B., Donatti D.A., Vollet D.R. // Appl. Phys. B. 2013. V. 111. P.103.

[155] Gallego-Gomez F., Del Monte F., Meerholz K. // Nature Mater. 2008. V. 7. P. 490.

[156] Provenzano C., Pagliusi P., Cipparrone G., Royes J., Pinol M., Oriol L. // J. Phys. Chem. B. 2014. V. 118. P. 11849.
[157] Венедиктов В.Ю., Невская Г.Е., Томилин М.Г. // Опт. и спектр. 2011. Т. 111. С. 121; Venediktov V.Yu., Nevskaya G.E., Tomilin M.G. // Opt. Spectr. 2011. V. 111. P. 113.

[158] Sun Q., Wu P., Baig S., Lu H., Wang M.R. // Proc. SPIE. 2011. V. 7935. P. 79350Z-1.

[159] Zhu Y., Zhou Y., Chen Z., Lin R., Wang X. // Polymer. 2012. V. 53. P. 3566.

[160] Arora P., Podgornov F., Kozlovsky M.V., Kaur S., Biradar A.M., Haase W. // Phys. Scr. 2012. V. 85. P. 035405-1.

[161] Ortuño M., Márquez A., Gallego S., Pascual I., Beléndez A. // Intern. J. Polym. Sci. 2014. V. 2014. Art. ID 386736. P. 1.

[162] Bunning T.J., Natarajan L.V., Tondiglia V.P., Sutherland R.L. // Ann. Rev. Mater. Sci. 2000. V. 30. P. 83.

[163] Chen G., Ni M., Peng H., Huang F., Liao Y., Wang M., Zhu J., Roy V.A.L., Xie X. // ACS Appl. Mater. Interfaces. 2017. V. 9. P. 1810.

[164] Peng H., Bi S., Ni M., Xie X., Liao Y., Zhou X., Xue Z., Zhu J., Wei Y., Bowman C.N., May Y.-W. // J. Am. Chem. Soc. 2014. V. 136. N 25. P. 8855.

[165] Sun K.R., Kim B.K. // Polym. Adv. Technol. 2011. V. 22 P. 1993.

[166] Mao W., Sun Q., Baig S., Lu H., Wang M.R. // Proc. SPIE. 2012. V. 8258. P. 82581J-1.

[167] Nataj N.H., Mohajerani E., Jashnsaz H., Jannesari A. // Appl. Opt. 2012. V. 51. P. 697.

[168] Takanokura T., Kurashige M., Ishida K., Ohyagi Y., Watanabe M., Cho Y.H. // Proc. SPIE. 2011. V. 7955. P. $79550 \mathrm{~W}-1$.

[169] Liu Y.J., Lu M., Ding X., Leong E.S.P., Lin S.-C.S., Shi J., Teng J.H., Wang L., Bunning T.J., Huang T.J. // J. Lab. Automat. 2012. V. 18. P. 291.

[170] Redler A., Kitzerow H.-S. // Polym. Adv. Technol. 2013. V. 24. P. 7.

[171] Shishido A., Akamatsu N. // Proc. SPIE. 2012. V. 8475. P. $84750 \mathrm{~F}-1$.

[172] Sasaki T., Ikegami M., Abe T., Miyazaki D., Kajikawa S., Naka Y. // Appl. Phys. Lett. 2013. V. 102. P. 063306-1.

[173] Ryabchun A., Bobrovsky A., Sobolewska A., Shibaev V., Stumpe J. // J. Mater. Chem. 2012. V. 22. P. 6245.

[174] Jashnsaz H., Nataj N.H., Mohajerani E., Khabbazi A. // Appl. Opt. 2011. V. 50. P. 4295.

[175] Thomas J., Christenson C.W., Blanche P.-A., Yamamoto M., Norwood R.A., Peyghambarian N. // Chem. Mater. 2011. V. 23. P. 416.

[176] Tsutsumi N., Kinashi K., Nonomura A., Sakai W. // Materials. 2012. V. 5. P. 1477.

[177] Zarins E., Tokmakovs A., Kokars V., Ozols A., Augustovs P., Rutkis M. // Opt. Mater. 2016. V. 53. P. 146.

[178] Kinashi K., Wang Y., Nonomura A., Sakai W., Tsutsumi N. // Proc. SPIE. 2012. V. 8474. P. 84740T-1.

[179] Kinashi K., Wang Y., Nonomura A., Tsujimura S., Sakai W., Tsutsumi N. // Polym. J. 2013. V. 45. P. 665.

[180] Giang H.N., Kinashi K., Sakai W., Tsutsumi N. // Polym. J. 2014. V. 46. P. 59.

[181] Fontanilla-Urdaneta R.C., Olivares-Pérez A., FuentesTapia I., Ríos-Velasco M.A. // J. Phys.: Conf. Ser. 2011. V. 274. P. 012037-1.

[182] Frejlich J. Photorefractive Materials: Fundamental Concepts, Holographic Recording, and Materials Characterization. N.Y:: Wiley-Interscience, 2006. 
[183] Xu C., Zhang C.-L., Leng X.-S., Xu L., Xu Y.-H. // Chin. Phys. B. 2013. V. 22. P.054203-1.

[184] Fan Y., Xu C., Wang Y., Xia S., Guan C., Cao L. // J. Cryst. Growth. 2011. V. 318. P. 657.

[185] Xu C., Leng $X$., Xu L., Wen A., Xu Y. // Opt. Commun. 2012. V. 285. P. 3868.

[186] Xu C., Yang C., Zhu C., Sun T., Wang R., Xu Y. // Mater. Lett. 2012. V. 67. P. 320.

[187] Tian T., Kong Y., Liu S., Li W., Wu L., Chen S., Xu J. // Opt. Lett. 2012. V. 37. P. 2679.

[188] Sun T., Dai L., Xu C., Qian Z., Li D., Lin J., Wang R., $X u$ Y. // J. Molec. Struct. 2013. V. 1053. P. 1.

[188] Sun T., Dai L., Xu C., Qian Z., Li D., Lin J., Wang R., $X u$ Y. // J. Molec. Struct. 2013. V. 1053. P. 1.

[189] Mantashyan P. // Proc. SPIE. 2011. V. 7998. P. 79980J-1.

[190] Lv C., Hu Z.-j., Yan A., Jin Y., Chen H., Sun J. // Proc. SPIE. 2013. V. 8847. P. 88471F-1.

[191] Liu Y., Zhou Y., Zhu M., He C. // J. Nonlin. Opt. Phys. Mater. 2012. V. 21. P. $1250052-1$.

[192] Li X.-C., Qu D.-X., Zhao X.-J., Meng X.-J., Zhang L.-L. // Chin. Phys. B. 2013. V. 22. P. 024203-1.

[193] Marinova V., Liu R.C., Lin S.H., Hsu K.Y. // Opt. Express. 2012. V. 20. P. 19628.

[194] de Oliveira I., Carvalho J.F., Fabris Z.V., Frejlich J. // Proc. SPIE. 2013. V. 8785. P. $87852 \mathrm{~N}-1$.

[195] Sharma D., Gupta U., Mohan D. // J. Nonlin. Opt. Phys. Mater. 2012. V. 21. P. 1250053-1.

[196] Ryskin A.I., Angervaks A.E., Veniaminov A.V. // Holographic Materials and Optical Systems / Ed. by Naydenova I., Nazarova D., Babeva T. InTech, 2017. P. 405-433.

[197] Ryskin A.I., Shcheulin A.S., Angervaks A.E. // Mater. 2012. V. 5. P. 784.

[198] Щеулин А.С., Ангервакс А.Е., Рыскин А.И. // Опт и спектр. 2011. T. 110. № 4. C. 651; Shcheulin A.S., Angervaks A.E., Ryskin A.I. // Opt. Spectr. 2011. V. 110. N 4. P. 609.

[199] Щеулин А.С., Ангервакс А.Е., Вениаминов А.В., Захаров В.В., Рыскин А.И. // Опт. и спектр. 2014. Т. 116. C. 408; Shcheulin A.S., Angervaks A.E., Veniaminov A.V. // Opt. Spectr. 2014. V. 116. P. 379.

[200] Davidenko N.A., Dentarenko S.V., Getmanchuk Yu.P., Ishchenko A.A., Kozinetz A.V., Kostenko L.I., Mokrinskaya E.V., Studzinsky S.L., Skryshevsky V.A., Tretyak O.V., Chuprina N.G. // Mol. Cryst. Liq. Cryst. 2011. V. 535. P. 148.

[201] Davidenko N., Davidenko I., Ishchenko A., Kulinich A., Pavlov V., Studzinsky S., Chuprina N. // Appl. Opt. 2012. V. 51. P. C48.

[202] Давиденко Н.А., Давиденко И.И., Кравченко В.В., Мокринская Е.В., Павлов В.А., Солнщев В.С., Студзинский С.Л., Чуприна Н.Г. // Журн. прикл. спектр. 2016. T. 83. C. 647; Davidenko N.A., Davidenko I.I., Kravchenko V.V., Mokrinskaya E.V., Pavlov V.A., Solnzev V.S., Studzinsky S., Chuprina N.G. // J. Appl. Spectr. 2016. V. 83. P. 656.

[203] Гетманчук Ю.П., Давиденко Н.А., Кунитская Л.Р., Мокринская Е.В., Студзинский С.Л., Чуприна Н.Г. // Химия высоких энергий. 2013. Т. 47. С. 289; Getmantchuk Yu.P., Davidenko N.A., Kunitskay L.P., Mokrinskaya E.V., Studzinsky S., Chuprina N.G. // High Energy Chem. 2013. V. 47. P. 182.
[204] Гетманчук Ю.П., Давиденко Н.А., Кунитская Л.Р., Мокринская Е.В. // Высокомол. соед. В. 2013. Т. 55. C. 236; Getmantchuk Yu.P., Davidenko N.A., Kunitskay L.P., Mokrinskaya E.V. // Polym. Sci. B. 2013. V. 55. P. 88.

[205] Гетманчук Ю.П., Давиденко Н.А., Давиденко И.И., Кунитская Л.Р., Мокринская Е.В., Козел Г.И., Павлов В.А., Чуприна Н.Г. // Теор. экспер. химия. 2015. Т. 51. C. 96; Getmantchuk Yu.P., Davidenko N.A., Davidenko I.I., Kunitskay L.P., Mokrinskaya E.V., Kozel G.I., Pavlov V.A., Chuprina N.G. // Theor. Experim. Chem. 2015. V. 51. P. 104.

[206] Гетманчук Ю.П., Давиденко Н.А., Давиденко И.И., Мокринская Е.В., Павлов В.А., Чуприна Н.Г. // Теор. экспер. химия. 2015. Т. 51. С. 60; Getmantchuk Yu.P., Davidenko N.A., Davidenko I.I., Mokrinskaya E.V., Pavlov V.A., Chuprina N.G. // Theor. Experim. Chem. 2015. V. 51. P. 67.

[207] Yetisen A.K., Montelongo Y., Butt H. // Appl. Phys. Lett. 2016. V. 109. P. 061106-1.

[208] Guo J., Gleeson M.R., Sheridan J.T. // Phys. Res. Intern. 2012. V. 2012. P. ID 803439-1.

[209] Ordonez-Padilla M.J., Olivares-Pérez A., Vega-Criollo R., Berriel-Valdos L.R., Mejias-Brizuela L.R. // Proc. SPIE. 2011. V. 7957. P. 79570W-1.

[210] Pinto-Iguanero B., Olivares-Pérez A., Toxqui-López S., Fuentes-Tapia I. // Proc. SPIE. 2012. V. 8281. P. 828115-1.

[211] Mejias-Brizuela N.Y., Olivares-Pérez A., Grande-Grande A. // J. Phys.: Conf. Ser. 2011. V. 274. P. 012034-1. 